\title{
Se viene el malón \\ Las geografías afectivas del racismo argentino
}

\section{Gastón Gordillo \\ ${ }^{1}$ Departamento de Antropología. Universidad de British Columbia, Vancouver, Canadá ORCiD: 0000-0001-5292-7121 \\ Correo electrórnico: gordillo@mail.ubc.ca}

doi: $10.34096 /$ cas.i52.8899

Nota de los editores

Artículo elaborado especialmente para Cuadernos de Antropología Social a partir de la exposición del autor en las IX Jornadas de investigación en Antropología Social Santiago Wallace, noviembre de 2018. Buenos Aires, Sección de Antropología Social, Instituto de Ciencias Antropológicas, Facultad de Filosofía y Letras, Universidad de Buenos Aires.

\section{Palabras clave}

Raza; Racismo; Espacio; Afectos; Argentina

\section{Here comes el malón. The Affective Geographies of Argentine Racism}

\author{
Abstract \\ This article analyzes the spatial and affective dimensions of whiteness and racism in \\ Argentina by means of a counterpoint between "White Argentina," understood as the \\ project to create a white national geography, and "el malón" as allegory of the multi- \\ tudes that threaten this project. Through a spatial and affective reading of Argentine \\ history from the nineteenth century to the Macri government, I show that what most \\ often generates public expressions of racism in Argentina is the emergence into public
}

\section{Key words}

Race; Racism; Space; Affect; Argentina 
Palavras-chave

Raça; Racismo; Espaço; Afetos; Argentina

1. Nueve policías fueron detenidos en Tucumán por los saqueos. La Nación, 14 de diciembre de 2013; y Detienen a 16 policías y a una exagente por los saqueos en Córdoba. La Gaceta (Tucumán), 17 de febrero de 2014. space of crowds of poor or dark skinned people that evoke the return of "el malón": the indigenous cavalries that until the end of the nineteenth century put limits on the project of a Europeanized nation. This article shows how fear of el malón has been used to legitimize state terror -which I analyze with the figure of the "white malón"and how a "mestizo Argentina" that is critical of the racism of White Argentina and feels comfortable with the disjunctive multiplicity of the nation has gained ground in recent decades.

\section{O “malón” está chegando. As geografias afetivas do racismo ar- gentino}

\section{Resumo}

Este trabalho analisa as dimensões espaciais e afetivas da brancura e do racismo na Argentina por meio de um contraponto entre a "Argentina Branca", como o projeto de criação de uma geografia nacional do tipo europeu, e o "malón" como alegoria de multidões indígenas que ameaçam esse projeto. Através de uma leitura espacial e afetiva da história argentina desde o século XIX até o governo Macri, mostro que o que mais gera expressões públicas de racismo na Argentina é o surgimento no espaço público de multidões de pessoas pobres e tez morena, o que evoca o retorno do "malón": a cavalaria indígena que até o final do século XIX impôs limites ao projeto de uma nação europeizada. Este artigo mostra como o medo do malón tem sido usado para legitimar o terrorismo estatal -que analiso com a figura do "malón branco"- e como nas últimas décadas tem surgido, como contraponto e crítica ao racismo do projeto da "Argentina branca", uma "Argentina mestiça" que se sente à vontade com a multiplicidade da nação.

\section{Introducción}

En diciembre de 2013, los saqueos que sacudieron a Córdoba, Tucumán y otras ciudades del país sacaron a la luz las sensibilidades que han históricamente racializado a la geografía de la Argentina, algo por mucho tiempo negado por el discurso oficial del Estado. El 3 de diciembre, miles de policías en Córdoba entraron en huelga y se acuartelaron exigiendo un aumento salarial, mientras policías vestidos de civil empezaron a saquear negocios buscando que el público reclamara su regreso a las calles. Las imágenes de saqueos que no eran reprimidos se viralizaron en la TV y en las redes sociales y miles de hombres y mujeres de barrios pobres de Córdoba salieron a la calle y comenzaron a irrumpir en tiendas y supermercados para llevarse todo lo que pudieran, desde alimentos hasta televisores. Los disturbios se extendieron a otras provincias, especialmente a Tucumán, donde se desarrolló el mismo patrón de policías en huelga que se acuartelaron e incentivaron saqueos masivos. ${ }^{1}$ Con varias ciudades sacudidas por disturbios, una parte significativa de la población sintió que las calles se estaban disolviendo en medio de un vórtice salvaje creado por muchedumbres de "negros", el término despectivo usado en la Argentina para nombrar a los pobres y en general a personas con rasgos mestizos o indígenas.

Las redes sociales y los foros de los diarios La Nación y Clarín ebullían de comentarios que pedían el exterminio de "esos negros de mierda". Vigilantes armados comenzaron a dispararles a "los negros" como si fueran hordas salvajes avanzando sobre colonos de una frontera amenazada. Cuando La Nación tituló que "un joven" había sido asesinado a tiros en Córdoba, la mayoría de los lectores que comentaron en los foros 
celebraron su muerte como un acto de justicia civilizatoria. Muchos incluso criticaron que La Nación describiera a la víctima como "un joven"; para ellos era solo "un negro". Un lector agregó: "Lástima que sea solo uno. Ojalá que hubiera doscientos negros muertos". 2 Comentarios con un tono similar inundaron Twitter bajo el hashtag \#NegrosDeMierda. La violencia disminuyó dos días después, luego de que el gobierno nacional enviara fuerzas de gendarmería y que los gobiernos de Tucumán y Córdoba aceptaran las demandas salariales de la policía. Diez personas habían muerto y cientos quedaron heridas. Varios comentaristas compararon a las muchedumbres de saqueadores con las hordas de indígenas que en siglos pasados amenazaban las fronteras del espacio civilizado. En La Nación, Abel Posse (2014) describió que durante los saqueos en Tucumán un pariente suyo tomó prestada una escopeta, recluyó a su esposa e hijos en su casa y formó una patrulla de vigilancia con vecinos. Él sintió como si "un malón” estuviera por atacar su hogar: las multitudes de combatientes indígenas a caballo que en el pasado controlaban la mitad de lo que es hoy el territorio nacional.

El surgimiento de gestos y expresiones abiertamente racistas durante los disturbios de 2013 y su relación con la sensación de que "se viene un malón" contradice aquel viejo discurso que por mucho tiempo sostuvo que en la Argentina "no hay problemas de racismo", porque esta sería supuestamente una nación "homogénea" y "europea”. Durante la campaña presidencial de 1983, Raúl Alfonsín repetía en sus discursos que la ausencia de racismo era una de las virtudes de la Argentina y casi dos décadas más tarde el escritor Marcos Aguinis (2001) reiteraba la misma idea al iniciar su libro El atroz encanto se ser argentinos. Sin embargo, esta idea celebratoria de la sociedad argentina como libre de racismo ha coexistido con el uso cotidiano de un lenguaje y actitudes profundamente racistas para nombrar a "esos negros de mierda": a esos millones de argentinos que serían la parte no blanca y despreciable de la nación y que amenazan irrumpir desde sus villas y barrios populares para "invadir" los lugares civilizados y blancos de la Argentina. Esta racialización es parte también de una formación de clase, donde "los negros" hace además referencia a los pobres. De hecho, muchos niegan que el término "los negros" sea racista porque aludiría a una posición de clase antes que a un color de piel, con lo cual subordinan lo racial a la clase social. Sin embargo, que los pobres sean llamados "los negros" y no de otra manera revela cómo en la Argentina las sensibilidades raciales permean y estructuran percepciones de clase. Y cuando "los negros" aparecen en gran número y amenazantes en las calles, tal como sucedió a finales de 2013, es común escuchar llamados entrelazados con insultos racistas a su exterminio, porque serían hordas salvajes comparables a los malones del pasado.

Retomando el camino abierto por el antropólogo Hugo Ratier (1972, 1986) en su análisis pionero del racismo antiperonista y antivillero, en los últimos años un número creciente de autores ha analizado el gran "tema tabú” de la Argentina: el rol de la raza y el racismo en la historia y política nacionales (Margulis y Urresti 1998; Joseph, 2000; Guano, 2003; Briones, 2005; Segato, 2007; Belvedere et al., 2007; Chamosa, 2008; Adamovsky, 2009, 2012a, 2012b, 2013, 2016; Frigerio, 2009; Geler, 2010; Grimson, 2006, 2012; Alberto y Elena, 2016; Álvarez Leguizamón 2017; Vivaldi, 2019; entre otros). Esta literatura ha resaltado la notable contradicción que existe entre el discurso que presenta a la sociedad argentina como tolerante y la realidad cotidiana de una sociedad profundamente racializada y racista. Como lo señalara Alejandro Grimson (2012), en la Argentina la misma persona puede decir que vive en un país blanco sin racismo y al rato quejarse que el país está lleno de "negros de mierda". Esta tensa oscilación entre la negación y el reconocimiento de la otredad no-blanca es central en la especificidad de la blanquitud en la Argentina, pero sus dimensiones afectivas y espaciales suelen ser pasadas por alto. Grimson y otros autores han argumentado que la blanquitud argentina es un "mito" o una "ideología": un discurso que oculta la existencia de fuertes legados indígenas, mestizos o afro en el país, y que los vuelve invisibles para legitimar la celebración de lo europeo. Es indudable que la blanquitud en la Argentina tiene fuertes
2. Córdoba: murió un joven de 20 años en medio de los saqueos. La Nación, 4 de diciembre de 2013. 
dimensiones míticas e ideológicas inculcadas discursivamente desde los medios y el Estado (Belverde et al. 2007; Álvarez Leguizamón 2017). Pero como lo señala Achille Mbembe, el racismo opera sobre todo inconscientemente y por medio de "apetitos, afectos, pasiones, miedos" (2017, p. 31). Y estos afectos y pasiones se movilizan espacialmente.

En este trabajo, analizo a la blanquitud argentina como una sensibilidad espacial que, si bien está influída por discursos e ideologías, a su vez los excede por operar corporalmente; y propongo llamar a esta formación afectiva y espacial "la Argentina Blanca". Con este término, no me refiero a un actor bien delimitado y compuesto por gente de piel blanca. Muchos de los críticos más duros de la Argentina Blanca han sido argentinos y argentinas de piel clara y ojos azules, como el escritor Osvaldo Bayer o la Madre de Plaza de Mayo Nora Cortiñas. Y algunos de sus defensores tienen ascendencia indígena, como el exgobernador de Salta Juan Carlos Romero. En este sentido, concibo a la Argentina Blanca como un proyecto territorial y de clase que se manifiesta a nivel cotidiano en el deseo no siempre consciente de sentir que la geografía nacional es en gran parte europea. Pero este es un proyecto acosado e incompleto, negado por los millones de personas que llevan en sus cuerpos las huellas del sustrato no-europeo de la nación. La Argentina Blanca, en este sentido, es un afecto en el sentido relacional que Baruch Spinoza (1982) le diera a este concepto: como la capacidad de afectar y ser afectado por otros cuerpos. Y pocas cosas afectan más visceralmente a la Argentina Blanca que la aparición de "los negros" en el espacio público.

La naturaleza afectiva del racismo es clara en la reacción visceral que experimentó parte de la población ante los saqueos de diciembre de 2013, que respondió con la frase más definitoria del racismo argentino: "a esos negros de mierda hay que matarlos a todos". Estos llamados a una violencia genocida -este deseo de matarlos a todos- son racionalizados como una condena a la criminalidad; pero también expresan en algunos sectores odio ante la confirmación de que la Argentina no es un país blanco, así como vértigo ante la sensación de que estas multitudes abren un vórtice salvaje desde adentro del país. Un abismo que resucita al "malón” que los padres fundadores de la Argentina Blanca pensaron que habían exterminado pero que el pariente de Abel Posse en Tucumán "sintió” que había reaparecido durante los saqueos de diciembre de 2013.

Llamar a los saqueos un “malón” es ciertamente una alegoría, pues las muchedumbres urbanas de la Argentina actual son muy distintas a los combatientes indígenas a caballo que atacaban estancias en el siglo XIX. Pero hay una razón por la cual los saqueos de 2013 evocaron la memoria del malón en el sentido más material del término: ambos nombran "el poder generado por multitudes en movimiento". Los malones indígenas del pasado ciertamente ya no existen. Pero “el malón” también puede ser analizado, como propongo aquí, como una configuración corporal y afectiva que ha trascendido su condiciones históricas originales y nombra hoy el poder de la acción popular en las calles, lo que hace que "el malón" se haya vuelto parte del léxico argentino.

La negrura de "los negros" que forman los nuevos "malones" no alude a fenotipos africanos (si bien en algunos casos sí, según el contexto) ni a una adscripción indígenaétnica (véase Adamovsky, 2013); es la negación misma de la frágil blancura argentina. Irónicamente, por mucho tiempo era común escuchar en la Argentina que en este país no habría racismo "porque no tenemos negros", refiriéndose, en este caso específico, a personas de ascendencia africana. ${ }^{3}$ Esta frase es notable porque admite que el racismo

3. Para evitar confusiones, algunos usan la expresión "negro mota” o "negro-negro" para referirse a personas con fenotipos africanos en contraste con "negros" de rasgos indígenas-mestizos. existiría si el país tuviera una población afroargentina considerable $\mathrm{y}$, al mismo tiempo, borra que la Argentina sí tiene millones de "negros" que son objeto de gestos racistas por sus fenotipos mestizos/indígenas y su pertenencia de clase. También borra el hecho de que hasta mediados del siglo XIX existía un considerable población afro en Buenos Aires y otras partes del país, que fue luego desmarcada como tal, mestizada 
y silenciada (Grosso, 2008; Geler, 2010, 2016; Frigerio, 2013). En resumen, el vértigo creado por la expansión espacial de "los negros" evoca no solo a los pobres, sino también al legado de múltiples fenotipos no-europeos en el país, sobre todo los de la población indígena y mestiza contra la cual los padres fundadores de la Argentina Blanca como Sarmiento y Roca definieron su proyecto.

El esfuerzo por hacer de la Argentina un país europeo en América del Sur ha sido un proyecto impugnado y desafiado desde posturas muy diferentes, y en las últimas décadas ha perdido parte de su antiguo prestigio y poder hegemónico. Estas disputas han sido profundamente espaciales, y en este trabajo analizo cómo han involucrado la acción en las calles de multitudes que suelen evocar el regreso del malón. En particular, mi objetivo es releer algunos momentos clave de la historia argentina por medio del lente de la raza, el racismo y sus dimensiones emocionales-espaciales desde el siglo XIX hasta el gobierno de Mauricio Macri. Espero mostrar, en particular, cómo el miedo al "regreso del malón" suele llevar a legitimar la violencia estatal contra expresiones populares de descontento. Pero antes de ello presento la idea de la Argentina Blanca como proyecto racial-territorial y como sensibilidad en relación con el espacio.

\section{La Argentina Blanca: la hegemonía afectiva de un proyecto asedia- do}

Una vasta literatura nos ha enseñado que la raza no es una categoría biológica, sino una construcción biopolítica que toma rasgos corporales visibles para dividir a grupos humanos en unidades supuestamente diferentes entre sí. La blanquitud o la negrura son, por ende, posicionamientos cuyos significados y límites son arbitrarios y negociables, pero a su vez controlados y esencializados. Y los posicionamientos racistas operan espacialmente. Como lo señalara Sarah Ahmed (2007), la blanquitud es una disposición afectiva y habitual hacia el espacio que "orienta los cuerpos en direcciones específicas, afectando cómo 'ocupan' el espacio". Y en situaciones de discriminación estas orientaciones son, para Ahmed, un "hábito malo" (bad habit), "una serie de acciones que son repetidas, olvidadas y que le permite a algunos cuerpos ocupar el espacio por medio de la restricción de la movilidad de otros" (Ahmed, 2006, p. 129).

En la Argentina, desde el Estado y las clases dominantes se fomentó una disposición hegemónica de blanqueamiento del espacio y de restricción de la movilidad de cuerpos no-blancos a partir de un proyecto particularmente ambicioso y racializado de ingeniería social: el intento de reemplazar completamente las poblaciones indígenas, mestizas y afro preexistentes con gente proveniente de Europa. Esto condujo al mito fundador de la Argentina Blanca: que la migración europea fue tan masiva y el exterminio de indígenas tan extremo que eventualmente el país se volvió racialmente homogéneo. Como lo ha argumentado Mónica Quijada: "Es difícil encontrar un caso en el que la pulsión homogenizadora haya tenido tanto éxito en la consolidación de una percepción colectiva de nación pretendidamente uniforme en términos culturales, étnicos y raciales" (2000, p. 10). Pero esta percepción hegemónica implicaba lo que Ann Stoler (2009) llama una condición afectiva de desatención (disregard): esto es, una incapacidad de prestarle atención o de reconocer ciertos rasgos de la realidad, en este caso que la sociedad argentina no es racialmente homogénea y que existen millones de argentinas y argentinos de tez oscura que viven en lugares (villas, barrios populares, "el interior") que son racializados como no-blancos. Muchos autores han notado que la gente que se identifica como blanca tiende a naturalizar su blanquitud como una normalidad no-racializada y a proyectar características explícitamente "raciales" a poblaciones no-blancas (Dyer, 1997; Hill, 1997; Ahmed, 2006). Esta normalización e invisibilización de la blanquitud ha sido profunda en la Argentina. El contraste con los Estados Unidos es ilustrativo: en aquel país la blanquitud ha incluido el uso corriente 
4. No los dejaron viajar debido a su apariencia. La Nación, 14 de julio de la palabra whites, "blancos", para marcar sus diferencias con los afroamericanos y latinos. En la Argentina, en cambio, hasta no hace mucho tiempo el término "los blancos" casi nunca era utilizado como marcador identitario por parte de personas de ascendencia europea, porque la blanquitud argentina se asumió durante mucho tiempo como una normalidad que no necesitaba ser nombrada. Pero al nombrar regularmente a "los negros" como la parte no-blanca de la nación, este sentido común admite que la blancura argentina es un proyecto incompleto y regularmente sujeto a fricciones en las calles con multitudes de gente "morocha".

Como parte de una resistencia emotiva a aceptar que personas sin rasgos europeos pudieran ser argentinas, este sentido común tiende a considerar la presencia de gente de piel oscura como intrusiones extranjeras. En 1999, por ejemplo, tres hermanos argentinos residentes en Buenos Aires fueron detenidos en el aeropuerto de Ezeiza y forzados a perder su vuelo a los Estados Unidos porque los funcionarios de migraciones pensaron que su piel era demasiado oscura como para que fueran argentinos. Por ende, asumieron que sus pasaportes eran falsos. Estos hombres fueron registrados, maltratados e insultados como "boliguayos", un insulto racista que fusiona a Bolivia y Paraguay como una entidad indiferenciada y definida por gente de piel cobriza. ${ }^{4}$

Estudios etnográficos sobre el racismo argentino han mostrado que, junto con expresiones más públicas de odio racial, muchas formas de discriminación operan de manera oblicua, sutil o indirecta, disfrazada de un lenguaje no-racializado sobre valores, la seriedad, o la moralidad (Margulis y Urresti, 1998; Joseph, 2000); que existen fuertes diferencias regionales en cómo se manifiesta el racismo (Álvarez Leguizamón 2017); y que "los discriminados también discriminan", en muchos casos influidos por el lenguaje de los medios (Margulis y Urresti, 1998). Es bien conocido, por ejemplo, que en las clases populares la xenofobia antiboliviana es particularmente fuerte, lo que se puede constatar en los cánticos en canchas de fútbol (Belvedere et al., 2007). Este ensayo, en este sentido, no es un estudio etnográfico sobre la textura cotidiana del racismo argentino (algo explorado por varios de los autores citados). Adoptando una escala histórico-espacial más amplia, propongo analizar etnográficamente la evidencia que muestra que es sobre todo cuando multitudes de "negros" desafían límites espaciales que los odios racistas se manifiestan de manera más pública, negando su supuesta inexistencia. Y si bien el racismo argentino traspasa los límites de las clases sociales, me centro sobre todo en el de las clases medias y altas de Buenos Aires, pues el blanqueamiento del espacio argentino ha sido históricamente el proyecto de las élites porteñas que hicieron fortunas expropiando territorios indígenas y criollos.

A continuación, analizo el surgimiento histórico de este proyecto y cómo ha sido desafiado por multitudes que a menudo evocan la memoria del malón. El filósofo Jacques Derrida (1994) sostiene que los fantasmas son presencias que parecían haber desaparecido pero que siempre regresan, pues reaparecen una y otra vez. Hablar de espectros es, por ello, hablar de su regreso. Es en este sentido que el malón puede analizarse como una figura fantasmal: una fuerza que supuestamente fue destruida pero que, sin embargo, no deja de regresar para abrumar y atemorizar a quienes sueñan con una Argentina Blanca.

\section{La guerra contra el malón: la violencia fundante de la Argentina Blanca}

Uno de los rasgos definitorios de la historia argentina en las décadas posteriores a la independencia es que más de la mitad del territorio que la república reclamaba como propio estaba bajo el control de grupos indígenas: la Patagonia en el sur, el Gran Chaco en el norte, y la mayor parte de la llanura pampeana que rodea a Buenos Aires. Si bien 
estos grupos mantenían relaciones comerciales y políticas con las provincias argentinas, lo que definía su autonomía territorial era su poder para generar malones, los cuales desafiaban y negaban abiertamente la expansión territorial del poder estatal (de Jong y Cordero, 2017; Cordero, 2019). Durante buena parte del siglo XIX, los malones llegaban hasta las cercanías de Buenos Aires, pues "el desierto empezaba ahí nomás, a cuarenta leguas de la casa de gobierno" (Prado, 1960, p. 47). En Facundo, uno de los textos fundacionales del proyecto de la Argentina Blanca, Domingo F. Sarmiento declaró por ende que se sentía abrumado por la inmensidad del territorio controlado por "hordas salvajes". Este era el famoso “desierto", término que no aludía a una topografía desprovista de agua o vegetación, sino a un afuera salvaje más allá del alcance del poder estatal, la civilización y el capitalismo. Y lo que generaba este vaciamiento del espacio era justamente la capacidad de movimiento de los malones indígenas. Sarmiento reveló cómo se sentía afectado por este vacío cuando escribió que el desierto "se insinúa en las entrañas" (1999, p. 9). El malón se volvió por ello una de las figuras más notables de la literatura argentina, descripto por autores como Echeverría, José Hernández o Borges como una turbulencia que erosiona las representaciones y "esquiva los saberes": una "irrupción del acontecimiento" por el cual "el paisaje se pone en movimiento" (Rodríguez, 2010, pp. 17, 223; Gamarro, 2015). Y uno de los principales efectos del avance del malón era el vértigo.

Sarmiento escribió que sentía "una repugnancia invencible" por "los salvajes de las Américas" y agregó que su "exterminio" sería por ello "providencial" y "sublime". Esta es la contracara del miedo al malón: el llamado a aniquilarlo por medio del terror civilizatorio. Diego Escolar $(2007,2011)$ muestra que cuando fue gobernador de San Juan en la década de 1860 Sarmiento implementó esta política de terror al ordenar la masacre de gauchos rebeldes, por quienes él sentía tanta repugnancia como por los indígenas. Por ello, Escolar (2011) sostiene que la violencia fundante del Estado-nación fue no solo contra el malón indígena, sino también, décadas antes, contra las caballerías o "montoneras" gauchas, a las que Sarmiento veía como prácticamente equivalentes a los malones indígenas.

Siguiendo el legado de Sarmiento, el despliegue más violento de la larga guerra estatal contra el malón fue liderado por quien se convertiría en el héroe militar de la Argentina Blanca, el general Julio A. Roca, quien lideró las tropas que conquistaron el norte de la Patagonia en 1879 y supervisó como presidente (1880-86) la campaña al Chaco en 1884. En lo que muchos verían como un gran "malón blanco" (como veremos), la violencia del ejército derrotó la resistencia militar indígena y expandió de manera fabulosa la extensión territorial del Estado y el capitalismo. El genocidio indígena, la expropiación de enormes extensiones de tierra y la paralela llegada de millones de inmigrantes de Europa fueron parte de un esfuerzo por hacer de la Argentina una geografía racialmente nueva (véase Bayer y Lenton, 2010).

La producción de lugares de aspecto europeo se centró en la ciudad de Buenos Aires, Rosario y las provincias de Santa Fe, Entre Ríos, el sur de Córdoba y el norte y centro de la provincia de Buenos Aires: "La Pampa Gringa" o el corazón de la Argentina Blanca, la región donde se establecieron la mayoría de los inmigrantes europeos y donde las marcas de la antigua presencia indígena fueron mayormente borradas. En la Ciudad de Buenos Aires, varios barrios buscaron replicar la arquitectura y atmósferas de ciudades europeas para crear la "París de América del Sur". Y la numerosa población afro y mulata de Buenos Aires en el siglo XIX fue invisibilizada y blanqueada, algo acentuado por la dispersión de sus antiguos núcleos en los barrios de San Telmo y Montserrat hacia el resto de la ciudad (Geler, 2010). Este proyecto de blanqueamiento del espacio también se implementó en la Patagonia en la arquitectura de ciudades como Bariloche, donde se intentó replicar la atmósfera de los Alpes europeos (Chamosa, 2016).
5. El Progreso (Santiago de Chile), 27 de septiembre de 1844 . 
En medio de esta expansión territorial de una blanquitud hegemónica, a los grupos indígenas expropiados de sus tierras se les negaron durante décadas derechos de ciudadanía y se los trató como reliquias condenadas a desaparecer, pero también como una posible amenaza. En las primeras décadas del siglo XX, el Gran Chaco fue escenario de lo que se puede interpretarse como las primeras apariciones fantasmales del malón: la diseminación de rumores de que se venía "un malón" y que terminaron llevando a matanzas de gente indígena. Ello ocurrió en 1904 en San Javier (norte de Santa Fe), en 1924 en Napalpí (Chaco) y en 1933 en El Zapallar (Chaco), cuando el temor a un posible malón hizo que la policía y civiles armados masacraran a gente indígena (Mapelman, 2015; Valko, 2018). El mismo patrón se repetiría en 1947 en Formosa, como veremos. Pero al seguir un proyecto de dominación clasista, las élites nacionales tampoco dudaron en desatar el terror estatal sobre los inmigrantes europeos socialistas y anarquistas que desafiaban el statu quo. La masacre de cientos de trabajadores en Buenos Aires durante la Semana Trágica de 1919 o en las estancias ovejeras de la Patagonia en 1921 confirmó que el terror de la Argentina Blanca era no sólo racista sino parte de un proyecto de dominación de clase (véase Bayer, 1995).

A principios del siglo XX, funcionarios y académicos declaraban que el blanqueamiento de la nación había sido un éxito. Un juez, por ejemplo, argumentó con orgullo que la Argentina "es el único país blanco de América Latina" (citado por Chamosa, 2010, p. 114). Incluso los críticos liberales de la Conquista del desierto fomentaban este blanqueamiento cuando lamentaban que los indígenas hubieran sido "exterminados". Esta imagen de una nación blanca fue presentada en libros de texto y documentos oficiales con precisión matemática, donde se señalaba que la Argentina era "98 por ciento blanca", algo recientemente repetido como dato veraz en el CIA World Factbook (Chamosa, 2008, p. 77). Estas cifras eran significativas porque implicaban que la Argentina era la nación más blanca del mundo, ya que ni siquiera en los países escandinavos los blancos son el "98 por ciento" de la población. Pero estos porcentajes habían sido, literalmente, inventados. A finales del siglo XIX, los esfuerzos por homogeneizar a la nación incluyeron la eliminación del término "indio" y de toda categoría racial del censo, por lo que no había forma de saber cuántos ciudadanos no eran blancos (Grosso, 2008; Lazzari, 2010). Pero que el país seguía teniendo un sustrato indígena-mestizo era evidente, no solo visualmente, sino también en el continuo uso de un lenguaje racista para descalificar a las clases populares. Los seguidores del presidente radical Hipólito Yrigoyen (1916-1922, 1920-1930), el primero en desafiar a las élites terratenientes, eran llamados "negros", donde "la alusión racial evocaba toda una serie de falencias asociadas a la barbarie" (Adamovsky, 2013, p. 90). Y cuando la industrialización y urbanización de las décadas de 1930 y 1940 atrajeron a Buenos Aires a grandes cantidades de migrantes provenientes del interior, este lenguaje racializado se intensificó.

\section{La resurrección del malón: el peronismo como la invasión de los "cabecitas negras"}

La creciente presencia de gente trabajadora con poca o ninguna ascendencia europea en el tejido urbano de Buenos Aires, su movilización contra los privilegios de la aristocracia terrateniente y el surgimiento del peronismo como movimiento que tomó el poder del Estado fueron experiencias traumáticas para quienes habían soñado con una Argentina Blanca.

El 17 de octubre de 1945, este trauma se materializó en las multitudes de trabajadores que convergieron en la Plaza de Mayo en el centro de Buenos Aires para exigir la liberación del secretario de trabajo, el coronel Juan Domingo Perón, quien había sido encarcelado por el régimen militar por sus medidas pro-obreras, que eran inmensamente populares. Muchos comentaristas notaron que esta manifestación fue sentida 
como "una invasión" que tomó la ciudad (Milanesio, 2010). Esta movilización popular se extendió al resto del país y en febrero de 1946 Perón fue elegido presidente de la república. Su gobierno rompió con la previa hegemonía conservadora y, al ampliar los derechos de la clase trabajadora, los sectores opuestos a Perón empezaron a referirse a sus simpatizantes como "negros" y "cabecitas negras" (Ratier, 1972; Milanesio, 2010).

En las primeras presidencias de Perón (1946-1955), antiperonistas de todo tipo -desde la derecha católica hasta el Partido Comunista- expresaron que esta invasión de "cabecitas negras" a Buenos Aires marcaba el regreso del "malón” (Adamovsky, 2009, p. 277; Grimson, 2019, p. 66). Lo notable es que esta invasión fue sentida como salida "de la nada", lo cual creó entre muchos "un asombro metafísico" marcado por la pregunta “¿de dónde salieron?” (Gamarro, 2015, p. 171, 348-349). Este es el asombro de quienes estaban convencidos de que los malones y los indios habían sido exterminados. Como lo expresó un hombre citado por Hugo Ratier (1972, p. 13): "Pensamos que muchas tribus estaban extintas, pero una visita a Plaza Italia nos hizo cambiar de opinión". Como parte de esta racialización de las masas peronistas, La Nación apodó a Perón "el jefe de la tribu". Otro observador notó que las manifestaciones peronistas estaban llenas de "mestizos e incluso indios" y que por ello el país "se negreaba" (Adamovsky, 2009, p. 276). Este oscurecimiento tenía vetas subhumanas, pues esta invasión era sentida como un "aluvión zoológico", como lo dijo un diputado en el Congreso en 1947. Y el efecto visceral más común de esta expansión era, como lo había anticipado Sarmiento, el asco. En una revista antiperonista, se le preguntó a una persona qué pensaba de "las masas sudorosas" que apoyaban a Perón y respondió: “¡Me hacen sentir náuseas!" (Ratier, 1972, pp. 38, 32). Un periodista que había escrito que "el malón" había regresado junto con Perón argumentó que "este mal" debería ser "totalmente extirpado" (Adamovsky, 2009, p. 277). Adamovsky (2009) ha mostrado que la identidad de la "clase media" surgió en la Argentina como reacción contra el empoderamiento de la clase trabajadora durante los primeros gobiernos de Perón. Y estas citas muestran que estas clases medias se sentían blancas en oposición a la expansión espacial y política de "los cabecitas negras" e influenciadas por el racismo de las clases dominantes.

Pero como la Argentina Blanca era entonces un campo hegemónico que operaba a través de un sentido común y de emociones no reductibles a discursos ideológicos, los gobiernos peronistas erosionaron algunas de sus premisas mientras reprodujeron muchas otras.

\section{Del Malón de la Paz a la masacre de Rincón Bomba: el criollismo peronista y sus límites}

Como lo ha señalado el historiador Oscar Chamosa $(2008,2010)$, el peronismo de las décadas de 1940 y 1950 desafió la normalización de la blanquitud en la Argentina sobre todo en su celebración de las tradiciones criollas y mestizas del noroeste. Evocando las previas celebraciones criollistas de los gauchos y su mundo rural, los funcionarios peronistas hicieron frecuentes referencias a "los criollos" y apoyaron la difusión pública de su folklore, música y bailes. Adamovsky (2016) muestra que, además, el gobierno peronista hizo frecuente uso de imágenes visuales que enfatizaban el mestizaje argentino, como el escudo del Partido Justicialista con la imagen de dos brazos masculinos dándose la mano, uno de ellos blanco y el otro cobrizo. Esta visualización, no obstante, no era verbalizada en documentos escritos o en discursos en público. Otra ruptura con la ideología de las viejas oligarquías fue que se declaró oficialmente que los pueblos indígenas también eran ciudadanos argentinos al otorgarles, por primera vez, documentos de identidad (Gordillo, 2006; Gordillo y Hirsch, 2010). 
Estas políticas y estas aperturas hacia lo mestizo erosionaron en parte la idea de que la Argentina era una nación blanca y homogénea, pero no fueron lo suficientemente profundas. Como lo señala Diana Lenton (2010), el primer peronismo careció de una política explícita hacia los pueblos indígenas y reprodujo viejas formas de desatención a sus demandas. De manera similar, las celebraciones a favor de los criollos constituían alusiones despolitizadas que de hecho buscaban blanquearlos. La palabra "mestizo" rara vez se mencionaba y las referencias a los criollos tendían a minimizar sus legados indígenas (Lazzari, 2002; Escolar, 2007; Chamosa, 2008; Gordillo, 2018). Chamosa y también el historiador Eduardo Elena (2016) muestran que los funcionarios peronistas evitaban mencionar o criticar el racismo al que eran sometidos los criollos y los cabecitas negras. La ideología peronista, en este sentido, reconoció el componente mestizo de la nación pero lo hizo de manera tangencial, teniendo cuidado en enfatizar que la Argentina era un país "sin racismo" y definido por la "armonía racial" y además celebrando el legado del colonialismo español.

En 1946, estas contradicciones se hicieron evidentes durante la movilización de grupos indígenas conocida como El Malón de la Paz. Organizado para exigir títulos de propiedad en el noroeste del país, este "malón" fue un momento fundacional del movimiento indígena en el país. Coordinados por un oficial del ejército que simpatizaba con su causa, 174 hombres y mujeres caminaron desde las tierras altas de Jujuy a Buenos Aires en un viaje de tres meses. El nombre de la marcha revela, una vez más, el simbolismo del malón como expresión de afirmación indígena, esta vez como una caminata que se desplazó desde los márgenes de la nación hacia la capital. Pero este malón fue coreografiado como una marcha pacífica y respetuosa, muy diferente de los malones del pasado. Este malón por de pronto representaba "la paz", con lo cual se aceptaba implícitamente que los malones de combatientes a caballo habían sido derrotados. A medida que El Malón de la Paz avanzaba hacia Buenos Aires, la marcha ganó visibilidad y atención mediática en un país que no había sido testigo hasta entonces de este tipo de protesta por parte de pueblos indígenas. La presencia de un oficial del ejército en la marcha contribuyó a que esta fuera relativamente aceptable para las autoridades y que incluso generara expresiones públicas de simpatía (Lenton, 2010; Valko, 2010).

En Buenos Aires, la marcha fue recibida por curiosas multitudes peronistas pero, al mismo tiempo, grupos nacionalistas y fascistas protestaron por la presencia de "indios en la ciudad" (Valko, 2010, p. 195). Perón y miembros del Congreso recibieron brevemente al grupo para luego enviarlo con rapidez al Hotel de Inmigrantes, donde se albergaba a inmigrantes extranjeros recién llegados. Como lo ha señalado el escritor Marcelo Valko (2010), el simbolismo era claro: El Malón de la Paz no pertenecía a la Argentina. Unas pocas semanas después, la policía obligó al grupo a salir del hotel y, a fuerza de golpes y gases lacrimógenos, los obligaron a subir a trenes de carga que los llevaron de regreso a Jujuy. Posteriormente, Perón declararía que el Malón de la Paz no representaba "al auténtico habitante indígena de nuestro norte" (Serbín, 1981; Lenton, 2010; Valko, 2010). Aunque en los años siguientes el gobierno respondió a sus demandas expropiando haciendas en Salta y Jujuy y prohibiendo la servidumbre laboral, no alteró radicalmente el sistema de tenencia de la tierra del noroeste.

Es más, una de las peores masacres en la historia nacional tuvo lugar en Formosa bajo el primer gobierno de Perón. En octubre de 1947, tropas de gendarmería en contacto con el Ministerio del Interior asesinaron durante varios días a cientos de hombres y mujeres pilagá que se habían congregado en Rincón Bomba (cerca de Las Lomitas) y que habían generado temor y rechazo entre la población criolla de la zona. Como lo muestra Valeria Mapelman (2015), la masacre fue justificada en los medios de Buenos Aires en base a que "un malón" había atacado el pueblo de Las Lomitas, algo que nunca ocurrió. El diario Clarín incluso llegó a sugerir que este supuesto malón había sido influido por El Malón de la Paz del año anterior (Mapelman 2015). 
A pesar de su retórica y políticas inclusivas hacia el mestizaje argentino, los primeros gobiernos peronistas tendían a ver a los indígenas como colectivos extraños que no pertenecían del todo a la nación, excepto como reliquias destinadas a disolverse en el "crisol de razas" nacional. Los supuestos de la Argentina Blanca, inculcados desde el Estado por décadas, se habían convertido en el sentido común de diferentes clases. Y algunos de sus parámetros fueron aceptados como normales, como la negación de la existencia de racismo en el país. Esta continuidad fue clara en el hecho de que en Formosa cientos de personas desarmadas fueron masacradas por la gendarmería y que ello fue ocultado por décadas con el argumento de que se había repelido "un malón". La disposición a sentir que la Argentina debería ser blanca, no obstante, continuó teniendo un núcleo de clase: las élites y las clases medias antiperonistas cuyo desprecio por las multitudes de gente pobre y de tez oscura a menudo se transformaba en apoyo a la violencia.

\section{La reafirmación de la Argentina Blanca: auge y derrota del "malón revolucionario"}

Cuando las Fuerzas Armadas derrocaron a Perón en el golpe de 1955, estas buscaron no solo negar el legado del peronismo sino también reafirmar violentamente algunos de los parámetros racializados de la Argentina Blanca como proyecto territorial. Esta violencia comenzó en el fallido intento de golpe contra Perón en junio de 1955, cuando aviones de la marina ametrallaron, bombardearon y masacraron a cientos de civiles que se encontraban en la Plaza de Mayo manifestándose a favor del gobierno. Dicha masacre fue particularmente simbólica porque ocurrió en el mismo lugar donde una década atrás, en 1945, la aparición de una multitud había generado el nacimiento al peronismo, así como la sensación de que "el malón" había resucitado. Cuando Perón fue finalmente derrocado y exiliado en septiembre de 1955 y la autodenominada Revolución Libertadora tomó el poder, varios observadores notaron que la textura racial de las calles de Buenos Aires cambió. "Ya no ves cabecitas en el centro", señaló con sarcasmo un partidario del golpe (Ratier, 1972, p. 76). Ratier muestra que, con la amenaza del populismo contenida, el término "cabecita negra" desapareció gradualmente del lenguaje cotidiano porteño. El malón había sido repelido de Buenos Aires y el afuera salvaje parecía haberse disipado, al menos por un tiempo.

Pero hombres y mujeres del interior continuaron migrando a Buenos Aires y concentrándose en las barriadas precarias llamadas "villas miseria". Estos lugares cambiarían la geografía afectiva de la Buenos Aires blanca, que a partir de entonces empezó a sentir que los barrios prósperos y europeizados de la ciudad no estaban tan lejos de enclaves pobres y percibidos como peligrosos y racialmente oscuros. "Las villas", por ende, les dieron a los antiguos "cabecitas" y ahora "negros" el estatus de "villeros" (Ratier 1986; Guber, 2002). Las dictaduras militares que gobernaron el país en la década de 1960 intentaron remover estos lugares no deseados con programas de "erradicación de villas" que desalojaron a decenas de miles de personas que por ser "villeros" eran vistas como "un enemigo" (Ratier 1986, p. 86). Pero hacia fines de la década, la resistencia contra las erradicaciones terminó fomentando "un polo de resistencia popular" en un contexto en el que las movilizaciones y protestas en las calles se incrementaban en todo el país (Blaunstein, 2006).

En mayo de 1969, una rebelión de obreros y estudiantes tomó la ciudad de Córdoba por dos días en desafío a la dictadura de Onganía. "El Cordobazo" mostró en las calles la radicalización de buena parte de la población, donde la resistencia peronista que luchaba por el retorno de Perón de su exilio se entrelazó con la intensificación de las luchas revolucionarias en América Latina tras el triunfo de la Revolución Cubana de 1959. Rechazando la idea de una Argentina blanca, nuevas generaciones abrazaron 
imaginarios mestizos, indígenas y prolatinoamericanos para redefinir la nación (Elena, 2016). Creado en 1970, lo que se transformaría en el principal movimiento guerrillero del país se autodenominó "Montoneros" como homenaje explícito a los malones de gauchos del siglo anterior: las montoneras que lucharon contra las élites proeuropeas representadas por Sarmiento. Su bandera incluía una lanza cruzada con un fusil. Para los jóvenes radicalizados contra "la oligarquía", la reivindicación de los malones gauchos anclaba su lucha revolucionaria en el legado de previas rebeliones. En este clima político, las luchas indígenas también se incrementaron en todo el país con ocupaciones de tierras y movilizaciones de base, en algunos casos con el apoyo de activistas revolucionarios (Serbín, 1981; Iñigo Carrera, 1998).

Esta expansión espacial e insurgente de la efervescencia popular tuvo su eclosión en la victoria electoral en 1973 del candidato peronista Héctor Cámpora, quien le puso fin a la dictadura militar de 1966-1973 y asumió la presidencia aclamado por enormes multitudes en las calles. La Argentina Blanca experimentó entonces su hora más oscura, arrinconada por lo que sentía como hordas que mezclaban la barbarie subalterna con la amenaza de la revolución socialista. Pero poco después, Cámpora renunció para dejarle el poder a un Perón anciano que regresó de su exilio para terminar, poco antes de morir, con esa exuberancia revolucionaria. Una oleada de asesinatos por grupos paramilitares en 1974-75 y el golpe militar de marzo de 1976 llevaron a una campaña de terrorismo estatal que secuestró, torturó y asesinó a cerca de 30000 personas y logró con ello derrotar a las grandes movilizaciones de los años previos.

La dictadura de 1976-83 fue la encarnación más violenta del proyecto de la Argentina Blanca. En 1979, el régimen celebró el centenario de "la Conquista del Desierto" con desfiles militares y publicaciones que reivindicaban al general Roca y a los orígenes míticos de la Argentina Blanca, y trazaron una genealogía directa entre la lucha contra el malón indígena en el siglo XIX y la lucha contra la "subversión marxista" un siglo más tarde. Y en esos años, figuras y defensores de la dictadura señalaban que su objetivo era librar al país de "elementos ajenos al ser nacional". Esta purificación del espacio argentino de elementos "ajenos" a él incluía no solo a guerrilleros y militantes izquierdistas, sino también a lugares percibidos como bárbaros y racialmente foráneos como "las villas". En 1977, Osvaldo Cacciatore, el intendente de Buenos Aires durante la dictadura, retomó y expandió la "erradicación de villas" de la década anterior con el argumento de que allí se concentraban enfermedades, criminalidad, inmoralidad y extranjeros. Estos desalojos destruyeron miles de hogares a fuerza de topadoras y obligaron a abandonar la ciudad a unas 200000 personas, muchas de las cuales fueron simplemente "tiradas" fuera de los límites de la Capital Federal (hoy la Ciudad Autónoma de Buenos Aires) (Blaunstein, 2006). Uno de los objetivos de las topadoras fue la Villa 31, que está ubicada cerca de la Recoleta en el corazón de la Buenos Aires Blanca y había sido un centro de activismo político. Cientos de familias bolivianas que vivían allí fueron obligadas a subir a trenes con destino a Bolivia (Snitcofsky, 2017).

Sin embargo, la conmemoración que la dictadura hizo de la victoria sobre el malón y su remoción de "villeros" de Buenos Aires fueron, en retrospectiva, intentos infructuosos de exorcizar la realidad y masividad de una Argentina que no es blanca. Pocos años después, la Villa 31 y las otras villas que habían sido desmanteladas fueron gradualmente reocupadas y reconstruidas por multitudes espacialmente expansivas que, a pesar de la violencia a la que habían sido sometidas, no dejaron de regresar al centro de la ciudad blanca. 


\section{Se vienen los negros: los malones urbanos}

El incremento del desempleo y la pobreza creado por las reformas neoliberales aplicadas durante la dictadura de 1976-1983 y con vaivenes por los gobiernos constitucionales que le siguieron han acentuado la percepción de que las zonas más europeizadas y prósperas de la Argentina están rodeadas y amenazadas por villas miseria y barrios populares. Y estos lugares son imaginados como llenos de "negros" con la capacidad de generar formas disruptivas de movilidad.

Los saqueos realizados en mayo y junio de 1989 en medio de la hiperinflación que marcó el final de la presidencia de Raúl Alfonsín (1983-1989) significaron la aparición de uno de los "malones de negros" más masivos en la historia reciente argentina. Como alguien nacido y criado en Buenos Aires, en ese momento experimenté, siendo estudiante universitario, la atmósfera de miedo creada en las zonas prósperas de la ciudad ante la imagen en TV de multitudes de gente pobre saqueando comercios en las principales ciudades del país. Recuerdo, en particular, los rumores infundados de que "los villeros" avanzaban hacia el centro de la ciudad "por la avenida Rivadavia" en una oleada de lujuria, violencia y devastación, como si formaran un malón que habría roto el perímetro amurallado de un puesto asediado de la civilización. En varias zonas del Gran Buenos Aires y Rosario vecinos hicieron barricadas y prepararon sus armas de fuego esperando la aparición del malón (que nunca llegó). En esos días, el periodista Mariano Grondona, uno de los principales voceros de la Argentina Blanca, hizo su infame pedido por televisión de que era hora "de sacar los tanques a la calle" para hacer lo que el gobierno de Venezuela había hecho unos meses antes durante el "Caracazo" de febrero de 1989 en medio de una similar explosión de descontento popular: masacrar a los pobres que habían tomado las calles. Los tanques no llegaron a salir, pero la policía y civiles armados mataron a veinte personas e hirieron a cientos.

A fines de la década de 1990, como resultado del desempleo y la pobreza creados por las reformas neoliberales del presidente Carlos Menem (1989-1999), los límites espaciales que separaban a las clases sociales se endurecieron aún más con la proliferación de barrios cerrados y centros comerciales protegidos por seguridad privada (Svampa, 2001; Guano, 2003). Lo que George Cicciarello-Maher (2007) llama el temor de la clase media blanca a que sus lugares sean penetrados por gente pobre y de piel oscura llevó -al igual que en otras partes de Sudamérica- a una mayor vigilancia racializada de las calles por la policía, que a menudo detiene e interroga a gente de rasgos mestizos o indígenas (Margulis, 1998; Vivaldi, 2019).

Este miedo a la presencia de "los negros" en el tejido urbano se intensificó con el surgimiento del movimiento piquetero. Formado por miles de jóvenes desempleados que comenzaron a organizarse y a establecer bloqueos o piquetes en rutas y calles en varios lugares del país para exigir empleos y asistencia social, los piqueteros fueron rápidamente sentidos como la vuelta del malón. "Ayer malones, hoy piquetes", dijo un concejal de Morón en 2001, para luego reivindicar a Roca y "la matanza histórica de los aborígenes" para justificar la violencia que se merecerían los piqueteros. ${ }^{6}$ La Argentina Blanca siente a los piqueteros como "negros" particularmente temibles porque ocupan las calles con la cara cubierta y sosteniendo palos, lo que los muestra preparados y organizados para defenderse contra la policía. En 2003, La Nación encapsuló el odio de la Argentina Blanca por este malón moderno con un editorial titulado "El salvajismo de los piqueteros". ${ }^{7}$ Este título no fue un gesto inocente, ya que nombrar a alguien como "salvaje" es transformarlo en blanco legítimo de la violencia estatal. Esto fue lo que sucedió en "la masacre de Avellaneda" de junio de 2002, cuando durante una protesta la policía asesinó a dos activistas piqueteros, un hecho que un blog llamado sin rodeos Cuánto te odio negro de mierda celebró como "un acto de justicia".
6. Repudian expresiones consideradas xenófobas de un concejal de Morón. El Comercial (Formosa), 4 de septiembre de 2001.

7. El salvajismo de los piqueteros. La Nación, 13 de enero de 2003.

8. Como te odio negro de mierda (blog). Mayo de 2008. www.odioalosnegros.blogspot.ca/2008/05/ esta-nueva-entrada-es-para-recordarlos.html 
9. El odio, la otra cara de las redes sociales. La Nación, 15 de marzo de 2009.
En la Argentina, muchas personas de clase media y origen europeo son ciertamente críticas de estas celebraciones clasistas y racistas de la violencia. Pero gente progresista no está libre de reproducir parte del sentido común de la Argentina Blanca. A fines de la década de 1990, dos antropólogas basadas en los Estados Unidos, Galen Joseph (2000) y Emanuela Guano (2003), realizaron trabajo de campo en Buenos Aires entre gente de clase media que se oponía al programa neoliberal del entonces presidente Menem y notaron que sus críticas estaban profundamente racializadas. Muchos despreciaban a Menem por ser un "morocho" de una provincia pobre y mestiza (La Rioja) y expresaban una visión paternalista hacia los pobres que lo votaban. Guano también señaló que los maestros y maestras movilizados contra Menem celebraban a Sarmiento por su papel en la expansión de la educación pública y que, cuando se les preguntaba por el racismo de este último, negaban que ello fuera algo relevante. Y cuando estas etnógrafas sacaban el tema del racismo en la Argentina, sus interlocutores expresaban sorpresa y negaban con vehemencia que el racismo tuviera relevancia alguna en el país.

Una década más tarde, esta negación de la existencia de racismo en la Argentina se hizo más difícil de sostener dado el aumento dramático de grupos de Facebook que pedían el exterminio de "los negros". Estos grupos tenían nombres como "Odio a los negros", "Matar a todos los rastreros chorros negros de mierda", "Qué bueno sería un mundo sin negros, “No a los negros”. Incluso La Nación expresó preocupación por el odio racista celebrado por estos grupos. ${ }^{9}$ Estos grupos "antinegros" estaban formados mayormente por adolescentes que asistían a escuelas privadas de élite, lo que confirma el núcleo de clase de la Argentina Blanca y cómo chicos y chicas jóvenes reproducían los prejuicios de sus familias. Estos grupos fueron eventualmente cerrados por Facebook por violar sus reglas antidiscriminatorias, pero antes de ello guardé en 2008-2009 cientos de comentarios que muestran que estos llamados a la violencia respondían al sentimiento de que "los negros" se habían transformado en una presencia espacialmente asfixiante. Los comentarios decían cosas como "los negros están en todos lados", "se reproducen como ratas" y que iba a ser difícil exterminarlos por su abundancia: "Va a ser difícil. Son muchos". Muchos comentarios transmitían una sensación de náuseas ante esta "invasión" de lugares sentidos como propios y blancos como Recoleta: "Negros de mierda, ya no puede caminar tranquilo por Recoleta porque siempre hay un negrito cabeza... Deberíamos extinguir esa asquerosa raza”. En otras palabras, estos son llamados a una violencia no solo individual sino a escala genocida.

Como era de esperarse, estos grupos de Facebook negaban que fueran racistas. Algunos participantes argumentaban que no se referían a "negros de piel" sino a "negros de alma", y que por "negro" aludían a personas criminales, moralmente decadentes y peligrosas independientemente de su color de piel (una distinción que es común en los foros en línea y las redes sociales). Esta "distinción” revela cómo la Argentina Blanca niega su propia existencia y al mismo tiempo cómo siente el regreso de los malones como algo fantasmal, como si los indios salvajes del pasado hubiesen resucitado y se hubieran apoderado de cuerpos cuyas "almas" han sido oscurecidas. Este énfasis en personas que serían despreciables porque su "alma” es negra busca naturalizar jerarquías raciales con la declaración de que el salvajismo tiene un color oscuro. El lenguaje racista y progenocida predicado en estos grupos ya desaparecidos de Facebook puede sonar extremo pero es, de hecho, muy común en los foros en línea de Clarín y La Nación, tal como puede constatarse a diario.

Este odio de corte racista, como hemos visto, adquiere dimensiones explosivas cuando multitudes de gente pobre y morocha avanzan para ocupar lugares sobre los que reclaman derechos. Y ello está crecientemente asociado a un nuevo tipo de "negro de mierda": los inmigrantes recientes de Bolivia, Paraguay y otros países de América del Sur. En diciembre de 2010, un vórtice de movimiento, miedo y violencia se materializó 
en Buenos Aires cuando miles de personas, muchas de ellas inmigrantes recientes, ocuparon en masa el Parque Indoamericano - un gran parque cubierto de malezas en la zona más pobre del sur de la ciudad- y exigieron el derecho de edificar viviendas. Esta ocupación creó una gran conmoción que fue sentida como el regreso del malón. En Página|12, el artista Daniel Santoro (2010) escribió al respecto, "Parecen cosas del pasado, pero contra zanjas o puentes levantados, estos malones vuelven periódicamente desde la oscuridad de la barbarie".

Residentes de clase media-baja de los alrededores del parque empezaron a atacar a "los invasores" con piedras, bombas de gasolina e incluso con armas de fuego mientras proferían insultos racistas contra "los extranjeros" (véase Álvarez Leguizamón, Aguilar y Perelman, 2012). Los canales de televisión, las estaciones de radio y los foros en línea transmitían una sensación de alarma generalizada: un malón de extranjeros se había materializado de la nada y la territorialidad argentina se estaba desintegrando. La Nación enfatizó que los ocupantes del predio hablaban guaraní en sus campamentos. Una periodista dijo en vivo frente a las cámaras de televisión que la ocupación se debía a "una inmigración desenfrenada" que traía "inmigrantes de baja calidad" ${ }^{10}$ "Mañana puede ser nuestra casa", decía el título de un nota en La Nación que afirmó que esta insurgencia debería ser aplastada para evitar que se apoderara de la ciudad (Miglino, 2010), como si los hogares de Buenos Aires y la misma propiedad privada estuvieran amenazados por un malón de extranjeros.

El entonces intendente Mauricio Macri y buena parte de los medios atribuyeron este conflicto al "populismo" de las presidencias de Néstor Kirchner (2003-2007) y Cristina Fernández de Kirchner (2007-2015). En los foros en línea, miles de lectores clamaban que había que "matar a esos negros de mierda". Durante esos días, tres personas participantes de la ocupación fueron asesinadas por bandas armadas y la policía. Docenas más resultaron heridas. El gobierno nacional finalmente envió tropas de la gendarmería para detener la violencia y los ocupantes del parque lo abandonaron. Pero la aparición de esa multitud de "inmigrantes" había sido tan perturbadora como para transformar el espacio de Buenos Aires y abrir lo que fue sentido como un abismo salvaje.

En el año 2000, la revista semanal La Primera publicó una tapa memorable titulada "La Invasión Silenciosa", ilustrada con la imagen de un hombre de piel oscura, sin camisa, y con rasgos indígenas alterados con Photoshop para parecer desdentado, salvaje y amenazante. Detrás de él se ve el obelisco en el centro de Buenos Aires. El subtítulo proclamaba que "dos millones de inmigrantes ilegales" les quitaban el trabajo a "los argentinos". La foto usada para ilustrar a estos invasores resultó ser la de un hombre qom nacido en suelo argentino: un descendiente de las personas que han habitado lo que hoy es el territorio nacional durante milenios. Sin embargo, sus rasgos indígenas fueron usados para personificar la falta de blanquitud de los inmigrantes extranjeros latinoamericanos. Así, una blanquitud importada desde Europa como parte del legado de una invasión imperial fue presentada, en una notable inversión, como la condición natural de una Argentina que es "invadida" por los habitantes originarios de América. De manera reveladora, la portada de La Primera señala que los límites de Buenos Aires ya habían sido traspasados por este indio-extranjero, pues lo vemos parado junto al obelisco en el corazón de la capital argentina, como si acabara de bajarse de su caballo y puesto a descansar su lanza al finalizar el malón.

\section{El regreso de los indios: los nuevos malones indígenas}

En las últimas décadas, los pueblos originarios de todo el país han lanzado innumerables protestas, movilizaciones, ocupaciones y reclamos de tierras que han desafiado abiertamente la idea de la Argentina como una nación blanca y homogénea, lo cual
10. La Nación, 10 de diciembre de 2010 . 
revela que los pueblos indígenas nunca desaparecieron. El impacto institucional más destacado de este activismo fue la inclusión en la Constitución Nacional de 1994 de un artículo que reconoce que los pueblos indígenas son una parte constitutiva de la Argentina y preexistentes a ella, que terminó con el estatus de extranjeros proyectado sobre ellos desde la Constitución de 1853. Esta visibilidad constitucional fue resultado de movilizaciones por parte de colectivos autoidentificados como indígenas y que tuvieron históricamente una presencia social tangible en muchos lugares del país (como los pueblos mapuche, qom-toba o wichí), así como también por grupos que habían sido desmarcados como indígenas. En consecuencia, muchas personas y grupos se organizaron políticamente en torno a identidades que funcionarios y académicos habían considerado "extintas" o "en vías de extinción", como es el caso (entre otros) de los pueblos huarpe, rankulche y tehuelche (Escolar, 2007; Lazzari, 2010; Rodríguez, 2016).

En este contexto, muchos activistas celebran esta expansión como el regreso de ese viejo vector de rebeldía indígena: el malón. Ello fue claro en el autodenominado Segundo Malón de la Paz en Jujuy en agosto de 2006. Este "malón" consistió en marchas y cortes de ruta organizados por miles de hombres y mujeres de las tierras altas de Jujuy que buscaban conseguir los títulos de propiedad de sus tierras. Como lo indica el nombre de la protesta, los participantes se vieron como los herederos del primer Malón de la Paz realizado seis décadas antes. Muchas de las personas que cortaron las rutas eran, de hecho, nietos y nietas de quienes habían marchado a Buenos Aires en 1946. Pero el tiempo pasado también mostró cuán diferente era este nuevo Malón de la Paz. El primer malón había involucrado a menos de doscientas personas, fue liderado por un oficial del ejército, tuvo una actitud deferencial con Perón y terminó siendo enviado de regreso a Jujuy por la fuerza. El de 2006 no pudo haber sido más diferente: estuvo bajo el control de líderes indígenas y de asambleas de base y movilizó a miles de personas que confrontaron pacífica pero contundentemente a los agentes estatales. Los cortes de ruta fueron tan masivos que paralizaron a buena parte de la provincia, y el gobernador no tuvo más opción que ceder y negociar. A diferencia de su predecesor, el Segundo Malón de la Paz fue una gran victoria política que obligó al gobierno de Jujuy a comenzar a distribuir más de un millón de hectáreas de tierra a comunidades originarias (Gordillo, 2010).

La creciente visibilidad de las protestas indígenas ha encontrado una audiencia receptiva entre miembros de las clases medias urbanas que descienden de inmigrantes europeos pero que han comenzado a cuestionar la violencia y la discriminación impuestas a los pueblos indígenas. Pero muchos de los que todavía se aferran al ideal de una Argentina Blanca han seguido la expansión espacial de las demandas indígenas con hostilidad. El columnista de La Nación Rolando Hanglin es uno de los defensores más orgullosos de la Argentina Blanca y con frecuencia insiste que el malón ha resucitado y amenaza a la nación. En un artículo de 2013, Hanglin describió que el malón constituía "un ataque masivo de la caballería indígena" acompañado por "los gritos terroríficos de los guerreros" y que desencadenaba la devastación de "una población civil desarmada". Estos "crímenes", escribió, "siempre han merecido, a lo largo de la historia y en todas las naciones, las formas más severas de castigo". Hanglin entonces pasó a desarrollar su principal argumento: que a pesar de la campaña del general Roca, el malón no desapareció. "Todo esto es relevante para entender lo que sucedió en Chile la semana pasada", agregó, refiriéndose a una pareja de ancianos de apellido alemán que murieron cuando su casa se incendió en medio de conflictos de tierras con activistas mapuche. Una "horda", escribió Hanglin, había atacado a los terratenientes como un malón, en un acto de "terrorismo" que exigía una dura respuesta y que sería similar a las protestas mapuche en la Argentina (Hanglin, 2013). La Argentina Blanca puede verse una vez más como una orientación hacia el espacio que es sensible al movimiento de multitudes indígenas, pero no a la expropiación de sus tierras por colonos de origen europeo. Después de todo, la policía militar chilena había matado a militantes mapuches sin que 
ello perturbara a Hanglin. Aun así, este autor señaló una verdad: que la Conquista del Desierto no había logrado aniquilar por completo al malón.

Tres meses antes, el 13 de octubre de 2012, un "malón" moderno había, de hecho, aparecido en el norte de la Patagonia en uno de los lugares en la Argentina que más se han intentado europeizar: Bariloche. Unos cien activistas aparecieron armados con herramientas y cables de acero con la determinación de derribar el monumento que presenta al general Roca montado a caballo en el centro de la ciudad. Este monumento, cubierto durante mucho tiempo con grafitis que decían "asesino" y "genocida", era el blanco de una campaña por la eliminación de los monumentos a Roca que fuera iniciada por el escritor Osvaldo Bayer (Valko, 2013; Lenton, 2019). Ese día en Bariloche, la multitud ató las cuerdas al monumento, cortó parte de los pies del caballo de bronce y comenzó a tirar para derribarlo. El general petrificado comenzaba a inclinarse cuando la llegada de la policía logró salvar al monumento. En los foros de La Nación, la mayoría de los comentarios defendían apasionadamente el legado civilizador de Roca. Un comentario lo presentó como el pacificador de malones asesinos: "Roca no cometió ninguna masacre, las únicas masacres fueron cometidas por los malones". Pero los comentarios más iluminadores defendían el monumento, aunque también expresaban una resignada conciencia de que este ataque marcaba una nueva realidad hostil a la Argentina Blanca. "Deberíamos re-escribir la historia. No hubo conquista del desierto. Los indios ganaron. Y los hechos expuestos en este artículo lo demuestran". ${ }^{11}$ Este tono expresa la admisión de que el general Roca fracasó en su objetivo de crear una nación sin indios.

\section{La era kirchnerista: territorializaciones mestizas y topadoras sojeras}

La insurrección del 19 y 20 de diciembre de 2001 fue llevada a cabo por una multitud que enfrentó a la policía por el control del centro de Buenos Aires y forzó con ello la renuncia del presidente De la Rúa (1999-2001). Este fue un acontecimiento tanto histórico como espacial, porque marcó el colapso de la era neoliberal de Menem-De la Rúa y con ello le abrió el camino a la retórica y políticas "populistas" y prolatinoamericanas de los gobiernos de Néstor Kirchner y Cristina Kirchner. Como parte del "giro a la izquierda" del resto de América del Sur en esos años, se popularizaron en el país sensibilidades más abiertas a la idea de la Argentina como un país mestizo creado por múltiples legados. Este realineamiento fue claro en la celebración del Bicentenario de la Revolución de Mayo en 2010 en Buenos Aires. Como parte de un enorme desfile al que asistieron más de dos millones de personas, se representaron dos siglos de historia argentina abandonando el cuento de hadas de una nación homogénea y blanca y destacando, por el contrario, que la Argentina está definida por una multiplicidad de influencias indígenas, africanas, criollas y europeas (Adamovsky, 2012b). Esta celebración pública de la diversidad argentina hubiera sido impensable dos décadas antes y marcó una ruptura con el eurocentrismo de la celebración del Centenario realizada en 1910.

Pero esta apertura hacia el mestizaje heredada del primer peronismo es también expresión del hecho de que en las últimas décadas muchos jóvenes de clases subalternas se ven como "negros" como parte de su identidad y orgullo plebeyos. Como lo señala Ezequiel Adamovsky (2012a, 2013), ello no remite ni a una identidad afro diaspórica ni a una identidad étnica amerindia, sino que es una reivindicación de las dimensiones raciales de una identidad de clase, algo que comenzó a expresarse en la cultura popular durante el multiculturalismo neoliberal de la década de 1990. En 1994, por ejemplo, La "Mona" Giménez lanzó un álbum llamado Raza Negra en el que celebró "La piel de mi raza, la raza negra”. Esta identificación con una negrura plebeya se hizo aún más
11. En Bariloche intentaron derribar al monumento a Julio Roca. La Nación, 13 de octubre de 2012. 
destacada con la popularidad de la cumbia villera. Pablo Lescano, una figura en el género, lleva una tatuaje en el pecho que dice "100\% negro cumbiero", y cuando toca en vivo convoca a su público gritándoles "Las palmas de todos los negros, jarriba!" (Adamovsky, 2012a, p. 93). Diego Maradona, quien se crió en la pobreza, también ha declarado su orgullo de ser un "negro". Estos gestos públicos celebran lo negro en tanto posicionamiento subalterno y, por ende, reniegan de la idea misma de una nación blanca.

Estas reconfiguraciones también incluyen, desde la década de 1990, una reivindicación del malón en la culturar popular. El mejor ejemplo es tal vez la banda de rock metálico Malón y su éxito "Malón mestizo", cuya letra celebra la resurrección del malón: "Entre la negrada cansada y hambrienta/que rodea a la ciudad.../amontonados en villas de emergencia/resisten el manoseo imperial... Malón mestizo, hoy como ayer/Malón mestizo, tu causa es ley/Hoy somos miles los que le cantamos/a este rito de igualdad". Este es un malón mestizo e igualitario que emerge desde "la negrada" de las villas para avanzar sobre el territorio de la Argentina Blanca.

Quienes defienden el proyecto de la Argentina Blanca han respondido con horror a estas nuevas sensibilidades mestizas que celebran la negrura y los malones, y que se expandieron y consolidaron durante los doce años del kirchnerismo en el poder. El odio racista del primer antiperonismo, en este sentido, resurgió en el rechazo que el núcleo conservador de la Argentina Blanca siente por el "populismo K", temido como una amenaza izquierdista que buscaría hacer del país "Venezuela".

Este racismo se volvió particularmente intenso en 2008 durante el llamado "conflicto con el campo", cuando las patronales agropecuarias bloquearon rutas en zonas rurales y sus simpatizantes urbanos hicieron "cacerolazos" para protestar contra el intento del gobierno de Cristina Kirchner de aumentar las retenciones a las exportaciones agrícolas. Este fue el clamor de una Argentina Blanca que se sentía asediada por el avance de la barbarie populista y que se movilizó sobre todo en su principal núcleo espacial: Buenos Aires y la Pampa Gringa.

Desplegando su blanquitud para marcar lugares públicos como naturalmente propios, los "ruralistas" hicieron cortes contra el gobierno colocando tractores, camiones y camionetas en las rutas. Solo unos años antes, esas mismas personas solían llamar a los piqueteros "negros de mierda", "indios" y "salvajes" por hacer lo mismo: interrumpir el tráfico. En marzo de 2008, un periodista radial le preguntó al presidente de la Sociedad Rural Argentina, Raúl Biolcatti, qué pensaba de esta contradicción entre su fomento de los cortes de ruta "por el campo" y su condena a los cortes de ruta de los piqueteros. Sin inmutarse, Biolcatti respondió que lo que distingue a los piquetes hechos

por ellos es "el color de piel" de los participantes. ${ }^{12}$ En otras palabras, sus cortes eran legítimos por ser hechos por gente blanca. Los medios que apoyaban las protestas trataron a este comentario como irrelevante. Periodistas extranjeros que entonces estaban en la Argentina no podían creer que una figura política de tal relevancia pudiera hacer declaraciones abiertamente racistas en la radio sin sufrir repercusiones (Justo, 2008). Pero Biolcatti expresó un sentimiento generalizado entre los conservadores argentinos: que ellos representarían a la verdadera Argentina, amenazada por "negros" que votan ciegamente al peronismo a cambio de "un plan social y zapatillas". De hecho, los grupos de Facebook que pedían el exterminio de "los negros" alcanzaron su mayor expansión durante el conflicto con las patronales agropecuarias, y publicaban consignas antikirchneristas y promovían grupos de Facebook que apoyaban "al campo".

Uno de los momentos más ilustrativos de las dimensiones raciales del "conflicto por el campo" surgió el 25 de marzo de 2008, cuando la presidenta Cristina Kirchner llamó a los cortes "piquetes de la abundancia". Ello provocó un cacerolazo de protesta y una 
manifestación en Plaza de Mayo de gente que se movilizó sobre todo desde Barrio Norte y la Recoleta. Cerca de la medianoche, el dirigente piquetero Luis D’Elía respondió con una contramanifestación de piqueteros en la Plaza de Mayo a favor del gobierno. La periodista Mariana Moyano notó cómo una cronista de Canal 13 que estaba en ese momento en la plaza describió ante las cámaras el pánico y la huida de "la gente" que estaba a favor "del campo" ante el rumor de que se venía el malón piquetero:

“La gente corre, corre asustada buscando una vía de escape. [...] Escapan porque
es gente de clase media alta que sabe que están llegando los piqueteros", decía sin
filtro y con voz agitada y temblorosa la cronista de Canal 13 desde la Plaza de Mayo
el 25 de marzo de 2008. “La gente está asustada, se agarra de las manos...” porque
"los piqueteros están avanzando firmes arrasando todo a su paso" (Moyano 2010).

No hubo piqueteros "arrasando todo a su paso". Pero sí se generaron incidentes. Mientras caminaba hacia la Plaza de Mayo, D’Elía fue seguido de cerca por un manifestante "procampo" que lo insultó repetidamente como "negro de mierda" a lo largo de más de una cuadra y le gritó "negro mercenario represor". D’Elía finalmente reaccionó dándole una trompada frente a las cámaras de TV (algo por lo que después se disculparía en persona). A la mañana siguiente, D’Elía fue llamado por un periodista de radio que empezó la entrevista diciéndole "negro de mierda". Afectado por los eventos del día anterior, D’Elía respondió con una frase que se haría famosa: "Odio a los blancos". Dijo en particular que odiaba "a los blancos de la oligarquía" por su clasismo, racismo y por su violencia, ya que "nunca tuvieron ningún problema para matarnos en masa." ${ }^{13}$ Que un dirigente piquetero identificara en la radio a "los blancos" como objeto de su odio creó un alboroto a nivel nacional promovido por los medios de comunicación antikirchneristas. Periodistas y políticos condenaron en forma cuasi unánime a D’Elía por su "racismo" y "odio de clase". Pero casi nadie mencionó que tanto el hombre que lo había provocado en la calle, como el periodista que lo entrevistó, lo habían insultado antes como "negro de mierda", y que en esos días los foros en línea ebullían de odio racista y clasista contra D’Elía (Frigerio, 2009).

En una nota en La Nación, el politólogo Ariel Armory (2008) resaltó que los comentarios de D’Elía habían sido notables no solo por su crudeza, sino porque nombraron públicamente a un colectivo que está tan normalizado en la Argentina que se lo silencia sistemáticamente: "los blancos". La mención de esta palabra fue impactante, porque rompió con la normalización de la blanquitud al revelar que muchos argentinos y argentinas -y en este caso, un conocido dirigente piquetero y kirchnerista- no se identifican como blancos. Él hizo evidente que "los blancos" son solo una parte de la nación, no el todo. La intervención de D’Elía tuvo un impacto adicional, porque él se posicionó como un "negro" altanero (y kirchnerista) que le dice en la cara a la Argentina Blanca que les reciproca su odio. Su gesto resuena con algo analizado por Frantz Fanon (1986): que "ser negro" implica ser consciente de la hostilidad de la mirada de los blancos. D’Elía es el negro que les hace saber a "los blancos" que es bien consciente que él es odiado por ellos. "Ustedes creen que somos asquerosos, basura, barbarie", dijo, evocando el asco sentido por Sarmiento por indios y gauchos. Este incidente originado en fricciones afectivas creadas en las calles expuso lo que Michael Taussig (1999) llamaría el "secreto público" de la Argentina, algo que se oculta pero que en el fondo es bien conocido: que el racismo es parte de la infraestructura afectiva de la nación.

A pesar de haber desafiado a las viejas élites nacionales a través de su agenda más inclusiva, progresista y latinoamericanista, las administraciones de Néstor y Cristina Kirchner no terminaron de romper con la Argentina Blanca que los rechaza, pues muchas de sus políticas y narrativas reproducen las sensibilidades espaciales de aquel proyecto. Cristina Kirchner, en particular, hizo pública como presidenta su hostilidad al activismo ambientalista y originario, como lo mostró durante el conflicto de la
13. La historia detrás de la trompada. Página|12, 27 de marzo de 2008. 
14. Cristina, contra el Metrobús: ‘los árboles no se tocan'. Clarín, 16 de febrero de 2013.
15. Página|12, 25 de enero de 2018. comunidad qom de Félix Díaz con el gobierno kirchnerista de Formosa. Ello se debe en parte a que los Kirchner continuaron los parámetros racializados de destrucción espacial iniciados por la aristocracia terrateniente y a que bajo sus mandatos muchas áreas indígenas y mestizas han sido devastadas en nombre del progreso. Ello ha sido dramático en el Chaco argentino, donde el "boom de la soja" ha desmontado millones de hectáreas de bosques nativos y desalojado violentamente a miles de familias campesinas e indígenas para crear campos agrícolas (Aranda, 2011; Gordillo, 2018).

En febrero de 2013, el entonces intendente de Buenos Aires, Mauricio Macri, hizo derribar 150 árboles en el centro de la ciudad para crear el Metrobus. La presidenta Cristina Kirchner criticó duramente la medida y declaró su amor por los árboles. “iNo derribaremos ningún árbol! Los árboles son intocables. Son sagrados", dijo con vehemencia. Y agregó que bajo su gobierno los árboles serían destruidos "sobre mi cadáver". ${ }^{14} \mathrm{El}$ año anterior, cuarenta millones de árboles habían sido destruidos por topadoras en el Chaco argentino sin que ello la perturbara, lo que confirma que su amor por "los árboles" se limitaba a aquellos que están en lugares como Buenos Aires. Ahmed (2007) señala que los lugares adquieren el color de piel de sus habitantes. Una presidenta que desafió algunos de los parámetros de la Argentina Blanca replicó no obstante la indiferencia de esta última por la destrucción de bosques en las regiones con mayor proporción de campesinos mestizos y gente indígena en la Argentina.

\section{El malón blanco: el retorno al poder de la Argentina Blanca}

Así como la Argentina Blanca siente un odio visceral por las tendencias populistas, plebeyas y mestizas incentivadas por el peronismo y el kirchnerismo, su más acabada manifestación política en el siglo XXI ha sido hasta ahora el gobierno de Mauricio Macri (2015-2019), quien fue al menos brevemente "la gran esperanza blanca de La Argentina Blanca".

Mucho se ha escrito sobre el componente de clase del gobierno de Cambiemos, como que fue liderado por $\mathrm{CEO}$ y empresarios recibidos de universidades privadas que inmediatamente impusieron una agenda proempresarial, elitista y antipopular. Lo que me interesa resaltar aquí es la blanquitud y la espacialidad de este proyecto de clase. No es simplemente que los bastiones electorales de Macri han sido la Pampa Gringa y los barrios más blancos y prósperos de Buenos Aires. Si bien en general evitando los excesos de la ultraderecha (aunque a menudo flirteando con ella), la estética corporal y discursiva del macrismo se ha centrado en celebrar y naturalizar la blanquitud de la Argentina a múltiples niveles, como la celebración en TV de la blancura "pura" de la familia de Macri por parte de la conductora Pamela David ("Macri tiene una familiar blanca, hermosa, pura"); la demonización de protestas mapuche como "terrorismo" por parte de ministros macristas; las declaraciones xenófobas contra inmigrantes de América Latina; o la declaración que Macri hizo en Suiza de que "en Sudamérica somos todos descendientes de europeos" ${ }^{15}$ Pero donde el racismo y clasismo del gobierno de Cambiemos se hizo más palpable fue en la devastación social que generó entre los sectores populares al incrementar notablemente la pobreza y endeudar el país a niveles inéditos. Es por su saqueo racializado de la riqueza pública que la presidencia de Macri puede interpretarse como el regreso de un tipo muy distinto de malón: el malón blanco.

En la literatura de fronteras, el "malón blanco" es mencionado con frecuencia como la contracara del malón indígena y hace alusión a las entradas del ejército que causaban desolación en las tolderías. En Indios, Ejército y frontera, David Viñas señala que lo que distinguía a estos "malones blancos" de los malones indígenas es que eran "menos veloces pero más despiadados" (1982, p. 16). Los malones blancos eran además 
operaciones de saqueo que regresaban de entradas exitosas con numerosas cabezas de ganado, caballos y cautivos, muchos de los cuales solían terminar como sirvientes de familias acomodadas (Prado, 1960). En tanto vector de la expansión violenta de la territorialidad estatal y capitalista, la crueldad del malón blanco no concluyó con el fin de la conquista militar de la Patagonia y el Gran Chaco; tampoco se limitó a aterrorizar a gente indígena.

Como alegoría de la expansión expropiadora del Estado y las élites sobre territorios indígenas y las clases populares, "el malón blanco" apareció con fuerza en 1919 durante la Semana Trágica, en el bombardeo de Plaza de Mayo en 1955 y en todo el país durante la última dictadura militar; este término, en este sentido, puede verse como un concepto heurístico que ayuda a disolver la dicotomía civilización-barbarie celebrada por Sarmiento, pues nos recuerda que la demonización de las protestas populares suele esconder la violencia y los saqueos más devastadores de las élites.

El "malón blanco" del gobierno de Macri operó a diferentes escalas. En primer lugar, se manifestó en las jerarquías espaciales de sus políticas neoliberales de saqueo, lo que fue claro en abril de 2018 cuando Macri anunció que su programa para llevar "desarrollo" al norte del país sería llamado "la conquista del norte" ${ }^{16}$ Que para Macri el "desarrollar" la parte más indígena-mestiza del país implicara conquistarla muestra su apego a la violencia fundacional de la Argentina Blanca, así como su admiración por Roca (su prócer favorito). Ya en 2016, el ministro de Educación Esteban Bullrich había implicado que Macri lideraba la continuación del proyecto de conquista de Roca cuando declaró en la Patagonia que hacía falta "una nueva campaña al desierto, pero no con la espada, sino con la educación". ${ }^{17}$ Pero la "conquista" de territorios campesinos e indígenas no puede sino ser violenta, y suele involucrar el uso de grupos armados que actúan como malones blancos.

El 24 de septiembre de 2016, pocos días después de que Esteban Bullrich celebrara "una nueva campaña al desierto", quince hombres armados y encapuchados que se movían en tres camionetas aparecieron en la comunidad campesina de Bajo Hondo en el norte de Santiago del Estero, en una zona codiciada por empresarios. La patota fue enviada por el empresario Orlando Canido, dueño de la empresa de gaseosas Manaos y conocido en varias zonas del norte por sus intentos de desalojar pobladores para expandir campos agrícolas. Mientras las familias criollas huían al monte, estos hombres armados quemaron viviendas y ranchos, envenenaron un pozo de agua, mataron a seis vacas e hirieron a un campesino con un disparo de arma de fuego. Posteriormente se subieron a las camionetas y desaparecieron en la oscuridad. ${ }^{18}$ Solo unas semanas antes, en agosto de 2016, el presidente Macri había visitado la fábrica de gaseosas de Orlando Canido en la provincia de Buenos Aires. Con tono eufórico, Macri elogió a la empresa Manaos y a Canido, gritando a viva vos: “`Vamos Manaos! ¡Vamos Argentina!". La violencia del malón blanco, en este sentido, es la del impacto de políticas gubernamentales pero también la de grupos de hombres armados que avanzan con intención hostil sobre hogares subalternos.

Durante el gobierno de Macri, "los malones blancos que tuvieron" mayor impacto mediático fueron sin duda los ataques de la gendarmería y la prefectura naval en 2017 contra activistas mapuche que ocupaban tierras en disputa en el norte patagónico. Estos ataques condujeron a la muerte de Santiago Maldonado y al asesinato por la espalda de Rafael Nahuel. Como no podía ser de otra forma, la violencia de estas operaciones fue justificada por el gobierno y los medios como la respuesta civilizatoria contra los malones "terroristas" del activismo mapuche (véase Gutiérrez De Angelis, 2017; Lazzari y Lenton, 2018). En sus tapas, la revista satírica Barcelona parodió varias veces esta demonización macrista de las protestas mapuche como malones temibles: “¿Vuelve el malón? La lucha de la Gendarmería y el Gobierno contra los malones” (21/9/2017).
16. En Misiones, Macri arrancó con el operativo 'conquista del norte'. La Nación, 5 de abril de 2018.

17. Los repudios a la "campaña" de Bullrich. Página/12, 18 de septiembre de 2016.

18. Quema de ranchos y tiros contra campesinos en Santiago del Estero. Página 12, 24 de septiembre de 2016. 
19. Milagro Sala: Se aprobó el juicio político al titular de la Corte jujeña. Página|12, 7 de febrero de 2020.

20. Clarín, 13 de junio de 2018.

21. Página|12, 7 de abril de 2020.
Otra tapa dice, "Avanza imparable el extremismo y ya tomó la Patagonia”, ilustrada con el famoso cuadro de 1892 "la vuelta del malón”, pero retocado para mostrar a Santiago Maldonado armado de una lanza y liderando el malón (1/9/2017).

La represión del gobierno de Macri al movimiento piquetero y a movimientos sociales también fue justificada en términos similares: la necesidad de reprimir multitudes salvajes. El mejor ejemplo es la prisión (que lleva más de cuatro años) de la dirigente Milagro Sala en Jujuy, cuya antigua capacidad de movilizar multitudes de gente morocha y pobre con su organización Tupac Amaru así como su piel y pelos oscuros la volvieron el blanco de un odio racista particularmente intenso. En 2020, un miembro del Tribunal Supremo de Jujuy reconoció en un audio -lo que le valió enfrentar un juicio político- que "Milagro está presa porque este bendito tribunal entiende que si ella está suelta es un peligro para el gobierno; no por sus delitos, sino para que no tengamos que volver al quilombo permanente, a los cortes [de rutas], a la quema de gomas". ${ }^{19}$ En suma, Milagro fue enviada a prisión para contener su capacidad de organizar protestas colectivas.

En los últimos años, los imaginarios y miedos que evocan la memoria del malón también han sido redefinidos por el surgimiento de un movimiento feminista con una fuerte presencia callejera. Este movimiento se hizo masivo en la lucha por la legalización del aborto y en junio de 2018 rodeó el Congreso Nacional con una enorme manifestación que Luis Bruschtein (2018) llamó en Página|12 un "malón feminista”. No es sorprendente que la diputada Elisa Carrió se quejara en los pasillos del Congreso de que tal movilización era un "indigenismo urbanista" ${ }^{20}$ lo que muestra cómo el racismo del gobierno de Cambiemos se proyectó contra protestas que, aunque no se identificaran como indígenas, evocaban -en su masividad y expansión territorial- el retorno del malón.

La derrota de Macri a manos de Alberto Fernández en las elecciones de 2019 creó desazón en la Argentina Blanca. Este estado emocional se expresó en la movilización "de despedida" a Macri en la Plaza de Mayo antes de que dejara el poder. En su discurso, Macri les dijo a sus seguidores, muchos de ellos gente mayor y bien vestida, "Yo sé que muchos de ustedes sienten angustia por lo que viene" (Bruschtein, 2019). Y lo que "se viene" que les causaba angustia es el regreso, figurado pero real, del malón: un viejo miedo que tiende a alimentar lo peor del racismo y clasismo argentinos. Cuando la pandemia del coronavirus llegó a la Argentina en marzo de 2020, un concejal macrista de Córdoba dijo en un mensaje de voz privado filtrado a la prensa: "Yo lo único que espero es que esta pandemia haga una limpieza étnica que todos nos merecemos... Yo por mí que [el virus] se quede en La Matanza y le haga honor al nombre. Con cinco o seis millones de negros menos, de peronistas menos, de planes menos, capaz que este país arranca". 21

\section{Conclusiones: la Argentina mestiza}

En este artículo, he analizado la blanquitud en la Argentina como un proyecto territorial y una sensibilidad afectiva que están acosados por la imposibilidad de su realización. Y esta sensibilidad genera en muchos casos expresiones de odio racista ante la evidencia de que la Argentina es un país "lleno de negros", lo que se hace manifiesto sobre todo cuando multitudes de personas pobres toman las calles. Estas irrupciones han evocado de manera recurrente y en los más diversos contextos la memoria del malón: las insurgencias indígenas y gauchas que en el pasado le pusieron límites al proyecto de una nación europeizada. Lejos de haber desaparecido, la memoria del malón se ha vuelto una alegoría del poder de multitudes espacialmente expansivas y se ha actualizado, cual regreso fantasmal, en los momentos más conflictivos de la historia nacional. Y 
como hemos visto, el miedo al avance de multitudes sentidas como hordas salvajes ha sido constitutivo de lo que propongo llamar "la Argentina Blanca": la disposición no totalmente consciente a desear vivir en un país blanco. Este miedo al avance de "los negros" es inseparable de la historia del terror estatal en la Argentina y de lo que puede interpretarse alegóricamente como la violencia del "malón blanco". Este último término nos permite disolver la dicotomía entre civilización y barbarie que estructura la visión primitivista del malón, ya que nos recuerda que las expresiones más crueles de salvajismo en la Argentina han sido generadas por las clases dominantes, que suelen inventar la amenaza de malones inexistentes para justificar su violencia.

Si bien el proyecto de la Argentina Blanca sigue guiando múltiples formas de racismo y violencia, este ha perdido parte de su antiguo prestigio y está ahora en competencia con una formación emergente que podría llamarse "la Argentina mestiza": una disposición antirracista que se siente cómoda con la multiplicidad racial de la nación. Esta disposición difiere de la noción hegemónica de mestizaje que primó por mucho tiempo en América Latina, y que asumía que la mezcla étnico-racial llevaría a una fusión de diferencias que crearía un todo homogeneizado. En países como Brasil y México, esta celebración oficial del mestizaje como símbolo de naciones supuestamente homogeneizadas no ha hecho más que intentar silenciar su racismo estructural (Knight, 1990; Segato, 2007). Algo similar ocurrió en la Argentina con la (parcial) reivindicación del mestizaje criollo por el peronismo, que, como vimos, reprodujo el racismo antiindígena de la Argentina Blanca. Pero las prácticas populares que en la Argentina promueven desde la década de 1990 posicionamientos mestizos siguen un camino distinto, a tono con lo señalado por Laplantine y Nouss (2007) y Rivera Cusicanqui (2018): que el mestizaje no crea una fusión homogeneizante sino, por el contrario, un caleidoscopio donde distintos elementos mantienen su individualidad. El mestizaje argentino y sus usos políticamente liberadores están, por ello, definidos por un movimiento de tensión, vibración y oscilación que crea una multiplicidad sin resolver: una "síntesis disyuntiva" (Deleuze y Guattari, 1983) o lo que Rivera Cusicanqui llama (siguiendo la tradición aymara) ch'ixi,: una indeterminación "que nos permite sentirnos cómodos en y con la contradicción" (2018, p. 83).

La Argentina fue siempre una nación mestiza en este sentido disyuntivo, fluido y contradictorio, por más que ello haya sido silenciado por la fantasía de una nación blanca. La expansión política de esta formación mestiza requerirá afirmar esta multiplicidad disyuntiva en el espacio así como los derechos territoriales de los pueblos originarios; y este proyecto demandará, sobre todo, multitudes en las calles dispuestas a erosionar las desigualdades de la Argentina Blanca.

\section{Agradecimientos}

Este trabajo es una versión revisada y actualizada de "The Savage Outside of White Argentina", publicado en el libro Rethinking Race in Argentina, editado por Paulina Alberto y Eduardo Elena (2016, Cambridge University Press). Traducción de Avelina Brown. Revisión del autor.

\section{Sobre el autor}

Gastón Gordillo es profesor en el Departamento de Antropología de la Universidad de British Columbia, Vancouver (Canadá). Ha realizado investigaciones etnográficas en varios lugares del Gran Chaco y norte argentinos entre gente qomle'ec, guaraní y criolla. Ganador de una beca Guggenheim, es autor entre otros libros de Los escombros del progreso (2018, Siglo XXI; traducción de Rubble, ganador de una Mención Honoraria, 
Premio Victor Turner a la Escritura Etnográfica), Lugares de diablos (2010, Prometeo; traducción de Landscapes of Devils, ganador del Premio Sharon Stephens, American Ethnological Society), En el Gran Chaco (2006, Prometeo) y El río y la frontera (2002, Biblos, con Juan Martín Leguizamón). Ha compilado (con Silvia Hirsch) el libro Movilizaciones indígenas e identidades en disputa en la Argentina (2010, La Crujía). 


\section{Q Referencias bibliográficas}

》 Adamovsky, E. (2009). Historia de la clase media argentina: Apogeo y decadencia de una ilusión, 1919-2003. Buenos Aires: Planeta.

" Adamovsky, E. (2012a). Historia de las clases populares en la Argentina: desde 1880 hasta 2003. Buenos Aires: Sudamericana.

" Adamovsky, E. (2012b). El color de la nación Argentina: conflictos y negociaciones en la definición de un ethnos nacional, de la crisis al bicentenario. Jahrbuch fur Geschichte Lateinamerikas, 49, 343-364.

" Adamovsky, E. (2013). La dimensión étnico-racial de las identidades de clase en la Argentina. En F. Guzmán y L. Geler (Eds.), Cartografías afroamericanas (pp. 87-112). Buenos Aires: Biblos.

» Adamovsky, E. (2016). Race and Class Through the Visual Culture of Peronism. En P. Alberto y E. Elena (Eds.), Rethinking Race in Modern Argentina (pp. 155-183). Cambridge: Cambridge University Press.

"Aguinis, M. (2001). El atroz encanto de ser argentinos. Buenos Aires: Planeta.

"Ahmed, S. (2006). Queer Phenomenology: Orientations, Objects, Others. Durham: Duke University Press.

"Ahmed, S. (2007). A Phenomenology of Whiteness. Feminist Theory, 8, 49-168.

» Alberto, P. y Elena, E. (2016). Introduction: Shades of the Nation. En P. Alberto yE. Elena (Eds.), Rethinking Race in Modern Argentina (pp. 1-22). Cambridge: Cambridge University Press.

" Álvarez Leguizamón, S. (2017). Formas de racismo indio en la Argentina y configuraciones sociales de poder. Rosario: Prohistoria.

" Álvarez Leguizamón, S. Aguilar, M. y Perelman, M. (2012). Desigualdad urbana, pobreza y racismo: Las recientes tomas de tierra en Argentina. En Carlos Fidel y Enrique Valencia Lomelí (Eds.) (Des)Encuentros entre reformas sociales, salud, pobreza y desigualdad en América Latina. Tomo 1. (pp. 196-23). Buenos Aires: CLACSO-ASDI-Unqui.

" Aranda, D. (2011). Argentina originaria: genocidios, saqueos y resistencia. Buenos Aires: La Vaca.

" Armory, A. (2008). Lo que nos enseñó D’Elía. La Nación, 5 de abril de 2008.

» Bayer, O. (1995). La Patagonia Rebelde. Buenos Aires: Planeta.

"Bayer, O. y Lenton, D. (Eds.) (2010). Historia de la crueldad argentina: Julio A. Roca y el genocidio de los pueblos originarios. Buenos Aires: El Tugurio.

» Belvedere, C. Caggiano, S. Casaravilla, D. Courtis, C. Halperín, G. Lenton, D. y Pacheca, M. (2007). Racismo y discurso: Una semblanza de la situación argentina. En Teun van Dijk (Ed.), Racismo y discurso en América Latina. (pp. 35-88). Barcelona: Gedisa.

"Blaunstein, E. (2006). Prohibido vivir aquí: La erradicación de villas durante la dictadura. Buenos Aires: Cuadernos de Causa Popular.

"Briones, C. (2005). Formaciones de alteridad: contextos globales, procesos nacionales y provinciales. En C. Briones (Ed.), Cartografías argentinas: políticas indigenistas y formaciones provinciales de alteridad (pp. 11-43). Buenos Aires: Antropofagia-Geaprona.

"Bruchstein, L. (2018). Malón feminista. Página|12, 16 de junio de 2018. 
» Bruchstein, L. (2019). La plaza del odio. Página|12, 8 de diciembre de 2019.

" Chamosa, O. (2008). Indigenous or Criollo: The Myth of White Argentina in Tucumán's Calchaquí Valley. Hispanic American Historical Review, 88, 71-106.

"Chamosa, O. (2010). Criollo and Peronist: The Argentine Folklore Movement During the First Peronism, 1943-1955. En M. Karush y Chamosa O. (Eds.), The New Cultural History of Peronism: Power and Identity in Mid-Twentieth-Century Argentina (pp. 113-142). Durham: Duke University Press.

"Chamosa, O. (2016). People as Landscape: The Representation of the Criollo Interior in Early Tourist Literature in Argentina, 1920-1930. En P. Alberto y E. Elena (Eds.), Rethinking Race in Modern Argentina (pp. 53-72). Cambridge: Cambridge University Press.

» Ciccariello-Maher, G. (2007). Toward a Racial Geography of Caracas: Neoliberal Urbanism and the Fear of Penetration. Qui Parle, 16, 1-33.

» Cordero, G. (2019). Malón y política: Loncos y weichafes en la frontera sur (1860-1875). Rosario: Prohistoria.

»De Jong, I. y Cordero, G. (2017). El malón en contrapunto: Dinámicas de la diplomacia, el comercio y la guerra en la Frontera Sur. En G. Di Meglio y S. Serulnikov (Eds). La larga historia de los saqueos en la Argentina: De la independencia a nuestros días (pp. 63-89). Buenos Aires: Siglo XXI.

»Deleuze, G. y Guattari, F. (1983). Anti-Oedipus: Capitalism and Schizophrenia. Minneapolis: University of Minnesota Press.

»Derrida, J. (1994). Specters of Marx: The State of the Debt, the Work of Mourning, and the New International. Nueva York: Routledge.

» Dyer, R. (1997). White. Londres: Routledge.

»Elena, E. (2016). Argentina in Black and White: Race, Peronism and the Color of Politics, from 1940 s to the Present. En P. Alberto y E. Elena (Eds.), Rethinking Race in Modern Argentina (pp. 184-210). Cambridge: Cambridge University Press.

»Escolar, D. (2007). Los dones étnicos de la nación: Identidades huarpe y modos de producción de soberanía en la Argentina. Buenos Aires: Prometeo.

»Escolar, D. (2011). De montoneros a indios: Sarmiento y la producción del homo sacer argentino. Corpus, 1(2), 1-8.

» Fanon, F. (1986). Black Skin, White Masks. Londres: Pluto.

»Frigerio, A. (2009). Luis D’Elia y los negros: identificaciones raciales y de clase en sectores populares. Claroscuro: Revista del Centro de Estudios sobre la Diversidad Cultural, 8 , $13-43$.

» Frigerio, A. (2013). "Sin otro pecado que el color de su piel”: Imágenes del "negro" en la revista Caras y Caretas (1900-1910). En F. Guzmán y L. Geler (Eds.), Cartografías afroamericanas (pp. 151-172). Buenos Aires: Biblos.

» Gamarro, C. (2015). Facundo o Martín Fierro: Los libros que inventaron la Argentina. Buenos Aires: Sudamericana.

» Geler, L. (2010). Andares negros, caminos blancos: Afroporteños, estado y nación Argentina a fines del siglo XIX. Rosario: Prohistoria.

» Geler, L. (2016). African Descent and Whiteness in Buenos Aires: Impossible Mestizajes in the White Capital City. En P. Alberto y E. Elena (Eds.), Rethinking Race in Modern Argentina (pp. 213-240). Cambridge: Cambridge University Press.

» Gordillo, G. (2006). En el Gran Chaco: Antropologías e historias. Buenos Aires: Prometeo. 
» Gordillo, G. (2010). Deseando Otro Lugar: Reterritorilizaciones guaraníes. En G. GordiIlo y S. Hirsch (Eds.), Movilizaciones indígenas e identidades en disputa en la Argentina (pp. 207-236). Buenos Aires: Flacso-La Crujía.

» Gordillo, G. (2018). Los escombros del progreso. Buenos Aires: Siglo XXI.

» Gordillo, G. y Hirsch, S. (2010). La presencia ausente: políticas estatales, invisibilizaciones y emergencias indígenas en la Argentina. En G. Gordillo y S. Hirsch (Eds.), Movilizaciones indígenas e identidades en disputa en la Argentina (pp. 15-38). Buenos Aires: FLACSO-La Crujía.

" Grimson, A. (2006). “Nuevas xenofobias, nuevas políticas étnicas en la Argentina”. En Alejandro Grimson y Elizabeth Jelin (Eds.), Migraciones regionales hacia la Argentina: Diferencia, desigualdad y derechos. Buenos Aires: Prometeo.

» Grimson, A. (2012). Mitomanías argentinas: cómo hablamos de nosotros mismos. Buenos Aires: Siglo XXI.

» Grimson, A. (2019). ¿Qué es el peronismo? Buenos Aires: Siglo XXI.

» Grosso, J. L. (2008). Indios muertos, negros invisibles: Hegemonía, identidad, añoranza. Córdoba: Encuentro.

»Guano, E. (2003). A Color for the Modern Nation: The Discourse on Race, Class, and Education in the Porteño Middle-Class. Journal of Latin American Anthropology, 8, 148-171.

» Guber, R. (2002). “El cabecita negra” o las categorías de investigación etnográficas en la Argentina. En S. Visacovsky y R. Guber (Eds.), Historias y estilos de trabajo de campo en Argentina (pp. 347-374). Buenos Aires: Antropofagia.

» Guss, D. (2006). The Gran Poder and the Reconquest of La Paz. Journal for Latin American Anthropology, 11, 294-328.

» Gutiérrez De Angelis, M. (2017). La vuelta del malón: Cultura visual y violencia estatal en Argentina. e-imagen Revista 2.o. 4.

» Hanglin, R. (2013). Chile y Argentina, ¿Hacia una crisis mapuche? La Nación, 8 de enero de 2013.

» Hill, M. (Ed.). (1997). Whiteness: A Critical Reader. Nueva York: Nueva York University Press.

» Iñigo Carrera, N. (1998). La participación política de los indígenas chaqueños: algunos antecedentes, Misión Nueva Pompeya, 1952-1970. En A. Teurel y O. Jeréz (Eds.), Pasado y presente de un mundo postergado: estudios de antropología, historia y arqueología del Chaco Pedemonte Surandino (221-242). San Salvador de Jujuy: Universidad Nacional de Jujuy.

» Joseph, G. (2000). Taking Race Seriously: Whiteness in Argentina's National and Transnational Imaginary. Identities, 7, 333-371.

» Justo, M. (2008). Cuestión de piel. Página/12, 8 de abril de 2008.

» Knight, A. (1990). Racism, Revolution, and Indigenismo: Mexico, 1910-1940. En R. Graham (Ed.), The Idea of Race in Latin America, 1870-1940 (pp. 71-113). Austin: University of Texas Press.

»Laplantine, F. y Nouss, A. (2007). Mestizajes: de Arcimboldo a zombi. Buenos Aires: Fondo de Cultura Económica.

»Lazzari, A. (2002). Indio argentino, cultura (nacional): del Instituto de la Tradición al Instituto Nacional de Antropología. En S. Visacovsky y R. Guber (Eds.), Historias y estilos de trabajo de campo en Argentina (pp. 154-201). Buenos Aires: Antropofagia. 
»Lazzari, A. (2010). The Autonomy of the Appeared: Phantom Indian, Selves, and Freedom (on the Rankulche in Argentina). Tesis de doctorado. Departamento de Antropología, Columbia University. (Nueva York, EE.UU)

» Lazzari, A. y Lenton, D. (2018). Domesticar, conquistar, reparar: Ensayo sobre las memorias argentinas del olvido indígena. Etnografías Contemporáneas, 4, 63-80.

»Lenton, D. (2010). The Malón de la Paz of 1946: Indigenous Descamisados at the Dawn of Peronism. En M. Karush y O. Chamosa (Eds.), The New Cultural History of Peronism: Power and Identity in Mid-Twentieth-Century Argentina (pp. 85-111). Durham: Duke University Press.

»Lenton, D. (2019). Actitud Bayer. Corpus, 9(2), 1-7.

» Mapelman. V. (2015). Octubre Pilagá: Memorias y archivos de la masacre de La Bomba. Buenos Aires: Tren en Movimiento.

» Margulis, M. (1998). La discriminación en la discursividad social. En M. Margulis y M. Urresti (Eds.), La segregación negada: Cultura y discriminación (pp. 17-36). Buenos Aires: Biblos.

» Margulis, M. y Urresti, M. (1998). Introducción. En M. Margulis y M. Urresti (Eds.), La segregación negada: Cultura y discriminación (pp. 9-14). Buenos Aires: Biblos.

» Mbembe, A. (2017). Critique of Black Reason. Durham: Duke University Press.

» Milanesio, N. (2010). Peronists and Cabecitas: Stereotypes and Anxieties at the Peak of Social Change. En M. Karush y O. Chamosa (Eds.), The New Cultural History of Peronism: Power and Identity in Mid-Twentieth-Century Argentina (pp. 53-83). Durham: Duke University Press.

» Miglino, J. (2010) Mañana puede ser nuestra casa. La Nación, 12 de diciembre de 2010.

» Moyano, M. (2010). “Un debate Indoamericano”. Página|12, 17 de diciembre de 2010.

»Posse, A. (2014). Hay que salir al rescate de la nación. La Nación, 28 de enero de 2014.

» Prado, M. (1960). La guerra al malón. Buenos Aires: Eudeba.

»Quijada, M. (200o). Introducción. En Homogeneidad y nación: con un estudio de caso, Argentina, siglos XIX y XX (pp. 7-14). Madrid: Consejo Superior de Investigaciones Científicas.

» Ratier, H. (1972). El cabecita negra. Buenos Aires: Centro Editor de América Latina.

» Ratier, H. (1986) [1972]. Villeros y villas miseria. Buenos Aires: Centro Editor de América Latina.

» Rivera Cusicanqui, S. (2018). Un mundo ch’ixi es posible. Buenos Aires: Tinta Limón.

» Rodríguez, F. (2010). Un desierto para la nación: La escritura del vacío. Buenos Aires: Eterna Cadencia.

» Rodríguez, M. (2016). “Invisible Indians," “Degenerate Descendants”: Idiosyncrasies of Mestizaje in Southern Patagonia. En P. Alberto y E. Elena (Eds.), Rethinking Race in Modern Argentina (pp. 126-154). Cambridge: Cambridge University Press.

»Santoro, D. (2010). Otra vuelta del malón. Página/12, 19 de diciembre de 2010.

» Sarmiento, D. F. (1999). Facundo. Buenos Aires: Emecé.

"Segato, R. (2007). La nación y sus otros: raza, etnicidad e identidad religiosa en tiempos de la política de la identidad. Buenos Aires: Prometeo.

» Serbín, A. (1981). Las organizaciones indígenas en Argentina. América Indígena, 41, 407433. 
"Snitcofsky, V. (2017). La erradicación de villas en la ciudad de Buenos Aires: características específicas y contexto general (1976-1983). Clepsidra, 5(10), 54-75.

"Spinoza, B. (1982). The Ethics and Selected Letters. Indianapolis: Hackett.

"Stoler, A. L. (2009). Along the Archival Grain: Epistemic Anxities and Colonial Common Sense. Princeton: Princeton University Press.

"Svampa, M. (2001). Los que ganaron: la vida en los countries y barrios privados. Buenos Aires: Biblos.

» Taussig, M. (1999). Defacement: Public Secrecy and the Labor of the Negative. Stanford: Stanford University Press.

"Valko, M. (2010). Los indios invisibles del malón de La Paz. Buenos Aires: Madres de Plaza de Mayo.

» Valko, M. (2013). Desmonumentar a Roca: Estatuaria oficial y dialética disciplinadora. Buenos Aires: Sudestada.

»Valko, M. (2018). El malón que no fue: Historia y grietas de una masacre de película. Buenos Aires: Continente.

"Viñas, D. (1982). Indios, ejército y frontera. Mexico: Siglo XXI.

»Vivaldi, A. (2019). Indigeneidades urbanas: formaciones espacializadas de raza y experiencia Toba (Qom) en Buenos Aires. Quid, 16(11), 151-174. 